\title{
Practice of Mass Transport Model Application for Biogeochemical Redox Process in Aquifer
}

\author{
Osama Eljamal, ${ }^{1}$ E. D. P. Perera, ${ }^{2}$ and Kenji Jinno ${ }^{3}$ \\ ${ }^{1}$ Laboratory of Water Environment Engineering, International Education Center, Kyushu University, \\ 6-10-1 Hakozaki Higashi-ku, Fukuoka 812-8581, Japan \\ ${ }^{2}$ Geosphere Environmental Technology Corp. 6F, Hinoki Building, 2-1 Kanda, Ogawamachi, Chiyoda-ku, Tokyo 101-0052, Japan \\ ${ }^{3}$ Kyushu University, 1-4-5 Izumigaoka, Munakata City, Fukuoka 811-4162, Japan \\ Correspondence should be addressed to E. D. P. Perera, dumindapradeep@yahoo.com
}

Received 15 July 2011; Accepted 17 August 2011

Academic Editor: P. Grenni

Copyright (๑) 2011 Osama Eljamal et al. This is an open access article distributed under the Creative Commons Attribution License, which permits unrestricted use, distribution, and reproduction in any medium, provided the original work is properly cited.

Biogeochemical reduction processes are active in alluvial aquifers, because organic carbon which is indispensable for bacteria growth is abundant. As a result of reduction process, significant changes of groundwater quality take place; denitrification, reduction of manganese dioxide, iron-hydroxide, sulfate, arsenate, and methane are well known as reduction processes in an anaerobic groundwater condition. Therefore, the prediction of redox environment in an aquifer is a key subject in order to understand how the groundwater quality is affected. If the mechanism of groundwater quality formation in aquifer scale is systematically understood, impacts caused by accidents or illegal dumping can be predicted, and subsequently, an appropriate management of aquifer will be established. In the present paper, quantitative discussions are made by the numerical simulations applied for the one-dimensional column experiment and two-dimensional fresh-salt water mixing zone. Recommendation and the future subject are presented through the results of two numerical simulations.

\section{Introduction}

Groundwater quality is strongly affected by aquifer matrix and varies in space and time. Dissolution from base rocks and minerals, ion exchange, adsorption/desorption, decay and biological degradation are the major processes which should be taken into consideration when the characteristics of groundwater quality are discussed. Hydrological and hydrogeochemical factors are needed to be simultaneously considered because the chemical species are affected by the groundwater flow also. The application of the combined mass transport model with groundwater flow is therefore useful for analyzing the above processes quantitatively.

The bacteria mediated geobiochemical processes are significant amongst above processes, specifically in alluvial aquifers where human activity is intensive and impact of various waste is frequent; nitrate pollution is serious for drinking water. Dissolved manganese and iron released in the anaerobic aquifer are often the causes of unpleasant taste for drinking. Furthermore, sulfate and arsenite detected in anaerobic environment are both harmful for living beings $[1,2]$. Compared to the remarkable applications of the bacteria technology in the field of medical treatment and food industry, its application to the field scale geochemical study is yet limited. As the authors view, the papers by Kinzelbach and Schäfer [2], Lensing et al. [3], and Hunter et al. [4] have contributed to widen the modeling approaches to bacteria mediated processes taking place in aquifers. Their researches based on the hydrogeological coupled with bacteria mediated processes seem to be useful for better understandings of groundwater chemistry.

The present paper introduces two results of the numerical simulation. The one-dimensional numerical simulation for the column experiment is shown; the effect of the saw dust (organic carbon) as the electron donor for the enhancement to activate sequential reduction processes is discussed. The good agreement has been demonstrated through the detail comparisons with the measured concentration changes 


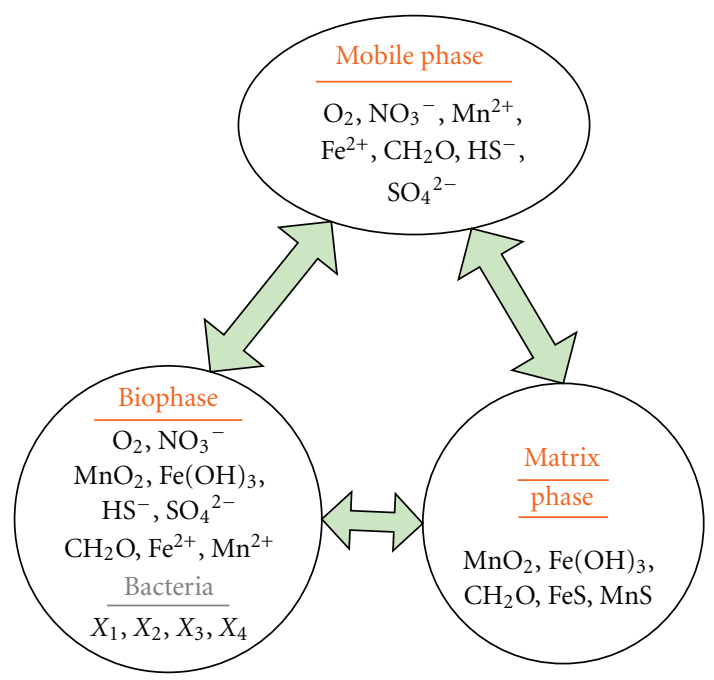

Figure 1: Chemical species considered in the redox model and species exchange between different phases.

of the reduced species [5].

The other result demonstrates qualitative study of the reducing process for the fresh-salt water lens in a sand spit aquifer. The numerical simulations for the two-dimensional unsaturated-saturated groundwater flow and the sequential reducing processes are presented. The numerical solution presents the two-dimensional spatial distributions of several geochemical species. Moreover, the distributions of all species which are considered in the redox modeling are presented along a selected bore hole. The result shows that the modeling approach is also useful to understand the mechanism of groundwater quality in fresh and salt water regions [6].

\section{Model Formulation}

2.1. Conceptual Model. The developed model describes the simulation of solute transport and biological processes in porous media by considering the interactions between electron acceptors $\left(\mathrm{O}_{2}, \mathrm{NO}_{3}{ }^{-}, \mathrm{Mn}^{2+}, \mathrm{Fe}^{2+}\right.$, and $\left.\mathrm{SO}_{4}{ }^{2-}\right)$ and electron donor $\left(\mathrm{CH}_{2} \mathrm{O}\right)$. The model also describes the release of metabolic products $\left(\mathrm{Mn}^{2+}, \mathrm{Fe}^{2+}\right.$, and $\left.\mathrm{HS}^{-}\right)$. Figure 1 shows the chemical species considered in the redox model and species exchange between different phases. The saturated porous media volume of each element is divided into three phases, the water or liquid as a mobile phase, the bacterial or biofilm as a biophase, and the remainder materials as a matrix phase. The biophase is assumed to include all bacterial metabolism processes. The organic matter is assumed to be present in matrix phase and it can dissolve into the mobile phase. Exchange processes are considered between the different model phases: (i) the mobile phase and the biophase, (ii) the mobile phase and the matrix phase, and (iii) the biophase and the matrix phase.

The model also explains the bacterial growth using double Monod kinetic equation, which is applied to defined four functional bacterial groups $\left(X_{1}, X_{2}, X_{3}\right.$, and $\left.X_{4}\right)$. The bacterial group $X_{1}$ uses oxygen under aerobic conditions and nitrate under anaerobic conditions as electron acceptors. Under anaerobic conditions bacterial groups $X_{2}, X_{3}$, and $X_{4}$ use $\mathrm{MnO}_{2}, \mathrm{Fe}(\mathrm{OH})_{3}$, and sulfate as electron acceptors, respectively.

2.2. Flow and Transport. This section describes mathematical equations which govern the two-dimensional water flow and transport of solute in porous media. For the one-dimensional column experiment, the flow rate can be constant if the hydraulic head at the inlet and outlet is maintained and clogging by bacteria growth is negligible [5]. On the other hand, the governing equations for the two-dimensional groundwater flow can be written as [6]

$$
\left(C_{w}+\alpha_{o} S\right) \frac{\partial h}{\partial t}=-\frac{\partial u}{\partial x}-\frac{\partial v}{\partial y},
$$

where $C_{w}$ is specific moisture capacity, $\alpha_{o}$ is switch number which takes to 0 for unsaturated condition or 1 for saturated condition, $S$ is specific storage coefficient, $h$ is pressure head, $t$ is time, $u$ and $v$ are Darcy's velocities in the $x$ and $y$ directions, respectively

$$
\begin{gathered}
u=-k \frac{\partial h}{\partial x} \\
v=-k\left(\frac{\partial h}{\partial y}+\frac{\rho}{\rho_{f}}\right),
\end{gathered}
$$

where $k$ is hydraulic conductivity, $\rho$ and $\rho_{f}$ are salt water density and fresh water density, respectively.

The fundamental two-dimensional partial differential equation governing the advective-dispersive solute transport of contaminants considering reaction part in the porous media can be written as [6]

$$
\begin{aligned}
\frac{d C_{i}}{d t}= & \frac{\partial C_{i}}{\partial t}+u^{\prime} \frac{\partial C_{i}}{\partial x}+v^{\prime} \frac{\partial C_{i}}{\partial y} \\
= & \frac{1}{\theta_{\mathrm{mob}}} \frac{\partial}{\partial x}\left(\theta_{\mathrm{mob}} D_{x x} \frac{\partial C_{i}}{\partial x}+\theta_{\mathrm{mob}} D_{x y} \frac{\partial C_{i}}{\partial y}\right) \\
& +\frac{1}{\theta_{\mathrm{mob}}} \frac{\partial}{\partial y}\left(\theta_{\mathrm{mob}} D_{y y} \frac{\partial C_{i}}{\partial y}+\theta_{\mathrm{mob}} D_{y x} \frac{\partial C_{i}}{\partial x}\right)+\sum_{j=1}^{2} S_{i, j},
\end{aligned}
$$

where $C_{i}$ is dissolved concentration of species $i$ in the mobile phase, $\theta_{\text {mob }}$ is the water content, $S_{i, j}(j=1,2)$ is chemical or biochemical reaction term; for $j=1$ or 2 , the dissolved species are exchanged with biophase or matrix phase explained below.

The dispersion coefficient tensor $D$, dependent on the real pore velocities, has the following components:

$$
\begin{aligned}
& D_{x x}=\frac{\alpha_{L} u^{\prime 2}}{V}+\frac{\alpha_{T} v^{\prime 2}}{V}+\tau \times D_{M}, \\
& D_{y y}=\frac{\alpha_{T} u^{\prime 2}}{V}+\frac{\alpha_{L} v^{\prime 2}}{V}+\tau \times D_{M}, \\
& D_{x y}=D_{y x}=\frac{\left(\alpha_{L}-\alpha_{T}\right) u^{\prime} v^{\prime}}{V},
\end{aligned}
$$


where $\alpha_{L}$ and $\alpha_{T}$ are microscopic dispersion lengths for longitudinal and transverse directions, $u^{\prime}$ and $v^{\prime}$ are components of real pore velocities calculated by $u^{\prime}=u / \theta_{\mathrm{mob}}$ and $v^{\prime}=$ $v / \theta_{\text {mob }}, V$ is absolute velocity calculated by $V=\sqrt{u^{\prime 2}+v^{\prime 2}}, \tau$ is tortuosity, and $D_{M}$ is molecular diffusion coefficient.

2.3. Exchange Processes. The source-sink term $S_{i, j}$ describes solute exchange between model phases. The solute exchange driving force is the difference between the concentrations of the species in different phases. The following equations describe the linear solute exchange when boundary film theory between the phases is applicable.

The exchange of solute between the mobile phase and the biophase $S_{i, 1}$ is expressed as

$$
\begin{aligned}
\theta_{\mathrm{mob}} S_{i, 1} & =\frac{\alpha(1-n)}{a} \cdot \frac{\theta_{\mathrm{mob}} \theta_{\mathrm{bio}} \sqrt{D_{L}}}{\theta_{\mathrm{bio}}+\theta_{\text {mob }}}\left(C_{\mathrm{bio}}-C_{\mathrm{mob}}\right) \\
& =\alpha^{\prime} \theta_{\mathrm{mob}}\left(C_{\text {bio }}-C_{\mathrm{mob}}\right) .
\end{aligned}
$$

The exchange of solute between the mobile phase and the matrix phase $S_{i, 2}$ is expressed as

$$
\begin{aligned}
\theta_{\mathrm{mob}} S_{i, 2} & =\frac{\beta(1-n)}{a} \cdot \frac{\theta_{\mathrm{mob}} \theta_{\mathrm{mat}} \sqrt{D_{L}}}{\theta_{\mathrm{mat}}+\theta_{\mathrm{mob}}}\left(C_{\mathrm{mat}}-C_{\mathrm{mob}}\right) \\
& =\beta^{\prime} \theta_{\mathrm{mob}}\left(C_{\mathrm{mat}}-C_{\mathrm{mob}}\right)
\end{aligned}
$$

where $C_{\text {bio }}$ and $C_{\text {mat }}$ are concentrations of solute in the biophase and in the matrix phase, respectively, $\alpha$ and $\beta$ are exchange coefficients between the phases, $\alpha^{\prime}$ and $\beta^{\prime}$ are simplified exchange coefficients, $n$ is porosity, $a$ is diameter of uniform soil particle and $\theta_{\mathrm{bio}}$, and $\theta_{\text {mat }}$ are specific volume of bio and matrix phases, respectively.

The low solubility of solid electron acceptors like $\mathrm{Fe}(\mathrm{OH})_{3}$ and $\mathrm{MnO}_{2}$ at near neutral $\mathrm{pH}$ values restricts their dissolution to values much too low. This assumption allows for the often observed microbial growth under iron and manganese reducing condition $[3,7]$. It is assumed that the $\mathrm{MnO}_{2}$ and $\mathrm{Fe}(\mathrm{OH})_{3}$ reducers use extracellular complex agent to access the solid electron acceptors [8]. Therefore, the mass exchange rate of $\mathrm{MnO}_{2}$ or $\mathrm{Fe}(\mathrm{OH})_{3}$ into the biophase is expressed by $S_{3, \text { bio }}$

$$
\begin{aligned}
\theta_{\text {bio }} S_{3, \text { bio }} & =\frac{\gamma(1-n)}{a} \cdot \frac{\theta_{\text {bio }} \theta_{\text {mat }} \sqrt{D_{L}}}{\theta_{\text {bio }}+\theta_{\text {mat }}}\left(C_{\text {mat }}-C_{\text {bio }}\right) \\
& =\gamma^{\prime} \theta_{\text {bio }}\left(C_{\text {mat }}-C_{\text {bio }}\right),
\end{aligned}
$$

where $\gamma$ is exchange coefficient between the matrix and biophases and $\gamma^{\prime}$ is its simplified exchange coefficient.

2.4. Biochemical Reactions. The growth of bacteria is considered only in the biophase. The growth of different groups of bacteria in the biophase is formulated by double Monod kinetic equation [9]

$$
\frac{\partial X}{\partial t}=v_{\max } \cdot \mathrm{IT}_{i} \cdot \frac{C_{1}}{K_{1}+C_{1}} \cdot \frac{C_{2}}{K_{2}+C_{2}} X,
$$

where $v_{\max }$ is maximum growth rate. The bacterial growth is limited by the inhibition term represented by $\mathrm{IT}_{i}=\mathrm{IC}_{i} /\left(\mathrm{IC}_{i}+\right.$ $C_{i}$ ) for the inhibiting species $i, C_{i}$ is its concentration and $\mathrm{IC}_{i}$ the inhibition constant, $C_{1}$ is electron donor concentration in biophase, $C_{2}$ is electron acceptor concentration in biophases, $K_{1}$ is electron donor half-saturation constant, $K_{2}$ is electron acceptor half-saturation, and $X$ is bacteria concentration.

The decay of bacterial population is described by the first order rate equation

$$
\frac{\partial X}{\partial t}=-v_{\mathrm{dec}} X,
$$

where $v_{\text {dec }}$ is constant decay rate. The net growth of bacterial population is the summation of (8) and (9).

The growth of bacteria population can increase based on one or more respirative pathways. For example, most of aerobic bacteria is facultative in an anaerobic environment and can also grow under denitrifying condition. The switching between aerobic and anaerobic conditions of bacteria groups depends on the oxygen concentration in their nearby environment, and can be written as [10]

$$
F\left(\left[\mathrm{O}_{2}\right]_{\text {bio }}\right)=0.5-\frac{1}{\pi} \tan ^{-1}\left\{\left(\left[\mathrm{O}_{2}\right]_{\text {bio }}-\left[\mathrm{O}_{2}\right]_{\text {thres }}\right) \times f_{\text {si }}\right\},
$$

where $F\left(\left[\mathrm{O}_{2}\right]_{\text {bio }}\right)$ is a switching function, $\left[\mathrm{O}_{2}\right]_{\text {bio }}$ is concentration of oxygen $\mathrm{O}_{2}$ in the biophase, $\left[\mathrm{O}_{2}\right]_{\text {thres }}$ is threshold concentration of oxygen $\mathrm{O}_{2}$, and $f_{\mathrm{s} 1}$ is slope of the switch function.

Bacterial activity in the porous media is mainly driven by the net decomposition of available organic carbon, which provides the energy to the bacteria [4]. Also, it is known that the bacteria uses only dissolved organic carbon chemically defined as $\mathrm{CH}_{2} \mathrm{O}$ and the utilizable portion of dead bacteria as electron donors [3]. The model is extended to include the simulation of organic carbon released from matrix phase, the initial concentration of releasable organic carbon from matrix phase can be written as follows:

$$
\left[\mathrm{CH}_{2} \mathrm{O}\right]_{\mathrm{mat}}^{\mathrm{O}}=R \frac{M_{\mathrm{CH}_{2} \mathrm{O}}}{n},
$$

where $R$ is the organic carbon coefficient and $M_{\mathrm{CH}_{2} \mathrm{O}}$ is total mass of carbon in matrix phase.

As a result of bacteria growth, metabolic products are released. They are related to bacterial growth via a production factor as [7]

$$
\begin{gathered}
\frac{\partial P_{\text {bio }}}{\partial t}=\frac{1}{P_{P}} \frac{\partial X}{\partial t}-\alpha^{\prime}\left(P_{\text {bio }}-P_{\text {mob }}\right) \\
P_{p}=S T \frac{Y_{O C}}{\left(1-Y_{O C}\right)}
\end{gathered}
$$

where $P_{\text {mob }}$ and $P_{\text {bio }}$ are the concentration of a metabolic product in mobile phase and biophase, $P_{P}$ is the production factor, $S T$ is the stoichiometric coefficient $(O C / C), Y_{O C}$ is the yield coefficient. 
TABLE 1: Chemical components of materials.

\begin{tabular}{|c|c|c|c|c|c|c|}
\hline Chemical species & Units & Soil & Sawdust & Chemical species & Units & Wastewater \\
\hline $\mathrm{Fe}_{2} \mathrm{O}_{3}$ & $\%$ & 7.5 & & $\mathrm{Na}$ & $\mathrm{mg} / \mathrm{L}$ & 95.2 \\
\hline $\mathrm{MnO}_{2}$ & $\%$ & 0.16 & & $\mathrm{~K}$ & $\mathrm{mg} / \mathrm{L}$ & 14.5 \\
\hline $\mathrm{Al}_{2} \mathrm{O}_{3}$ & $\%$ & 16.1 & & $\mathrm{Ca}$ & $\mathrm{mg} / \mathrm{L}$ & 40.3 \\
\hline $\mathrm{SiO}_{2}$ & $\%$ & 43.7 & & $\mathrm{Mg}$ & $\mathrm{mg} / \mathrm{L}$ & 9.2 \\
\hline Ig-loss & $\%$ & 5.9 & & $\mathrm{Fe}^{2+}$ & $\mathrm{mg} / \mathrm{L}$ & 0.13 \\
\hline $\mathrm{C}$ & $\%$ & 1.57 & 44.1 & $\mathrm{Mn}^{2+}$ & $\mathrm{mg} / \mathrm{L}$ & 0.137 \\
\hline $\mathrm{H}$ & $\%$ & 0.58 & & TOC & $\mathrm{mg} / \mathrm{L}$ & 5.6 \\
\hline $\mathrm{N}$ & $\%$ & 0.14 & 0.17 & $\mathrm{Cl}$ & $\mathrm{mg} / \mathrm{L}$ & 161 \\
\hline $\mathrm{pH}\left(\mathrm{H}_{2} \mathrm{O}\right)$ & - & & $5.1(20.1)$ & $\mathrm{NO}_{3}-\mathrm{N}$ & $\mathrm{mg} / \mathrm{L}$ & 10.5 \\
\hline $\mathrm{P}$ & $\mathrm{mg} / \mathrm{kg}$ & & 40 & $\mathrm{SO}_{4}$ & $\mathrm{mg} / \mathrm{L}$ & 40 \\
\hline K & $\mathrm{mg} / \mathrm{kg}$ & & 478 & $\mathrm{PO}_{4}-\mathrm{P}$ & $\mathrm{mg} / \mathrm{L}$ & 0.172 \\
\hline $\mathrm{NH}_{4}$ & $\mathrm{mg} / \mathrm{kg}$ & & 7.1 & & & \\
\hline $\mathrm{C} / \mathrm{N}$ & - & & 259 & & & \\
\hline
\end{tabular}

Based on (12), a typical equation representing the total change of iron in the biophase can be expressed by

$$
\begin{aligned}
& \frac{\partial}{\partial t}\left(\theta_{\mathrm{bio}}\left[\mathrm{Fe}^{2+}\right]_{\mathrm{bio}}\right) \\
& \quad=\frac{1}{P_{\mathrm{Fe}^{2+}}}\left[\frac{\partial \theta_{\mathrm{bio}} X_{3}}{\partial t}\right]_{\text {grow }}-\alpha^{\prime} \theta_{\mathrm{bio}}\left(\left[\mathrm{Fe}^{2+}\right]_{\mathrm{bio}}-\left[\mathrm{Fe}^{2+}\right]_{\mathrm{mob}}\right)
\end{aligned}
$$

\section{Application to One-Dimensional: A Column Experiment}

3.1. Column Experiment. The column experiment was carried out using transparent resin columns of $45 \mathrm{~cm}$ height and $10 \mathrm{~cm}$ internal diameter. The wire mesh $(0.1 \mathrm{~mm})$ and the filter paper (ADVANTEC no. 6) were placed at the bottom of each column. The top and the bottom of the column were closed using transparent resin plates with tubes $(20 \mathrm{~mm}$ diameter) inserted for the flow inlet and outlet.

The columns were packed up to a height of $30 \mathrm{~cm}$ with soil and sawdust. The first column was packed with $100 \%$ soil, while the second column was packed with a mixture of sawdust (50\%) and soil (50\%). The secondary treated wastewater was constantly supplied at the top of the two columns for 56 days and the average temperature was measured at $22^{\circ} \mathrm{C}$. The secondary treated municipal wastewater was supplied for the experimental period from Wajiro Wastewater Treatment Plant of Fukuoka City, Japan. The packed soil was collected from actual paddy field and sawdust was collected from local wood factory. Table 1 [11] shows the chemical concentration of the injection wastewater and the chemical components of paddy soil and sawdust.

The water level of waste water was maintained at $60 \mathrm{~cm}$ depth above the soil sawdust surface throughout the experiment by using the influent tank installed above the columns. The average flow rate was $0.009 \mathrm{~cm}^{3} / \mathrm{s}$ and $0.011 \mathrm{~cm}^{3} / \mathrm{s}$ for soil and soil-sawdust columns, respectively.

Influent and effluent samples were collected daily in glass bottles and then chemical composition was analyzed.
The cation concentrations were measured by the atomic absorption spectroscopy (ParkinElmar Japan, 3100 model), while anion concentrations were measured by the ion chromatography (Yoko Analytical Systems model). Electric conductivity, oxidation reduction potential, dissolved oxygen and $\mathrm{pH}$ were measured by electrode (DKK-TOA). Hydraulic heads were measured using piezometers located at 0,5 , 10,20 , and $30 \mathrm{~cm}$ below the sand-sawdust top surface of the each column. The values of piezometers were used for the calculation of hydraulic conductivity. The hydraulic conductivity of the columns was calculated from flux and water head by using Darcy's law. Flux was measured by the discharge rate of effluent from the outlet.

3.2. Model Setup. The developed model was applied to the one-dimensional column experiment to describes the interactions between $\mathrm{O}_{2}, \mathrm{NO}_{3}{ }^{-}, \mathrm{Mn}^{2+}, \mathrm{Fe}^{2+}$, and $\mathrm{SO}_{4}{ }^{2-}$ as electron acceptors and $\mathrm{CH}_{2} \mathrm{O}$ as electron donor and bacterial growth along of the column. The organic matter source used in the present experiment is sawdust which presents in matrix. The oxidation of organic carbon is paralleled by a sequence of reduction reaction which is presented in Table 2 [11]. The principal pathways of electron acceptors are aerobic respiration, denitrification, manganese reduction, iron reduction, and sulfate reduction. The model defines five redox reactions mediated by four different bacterial groups $X_{1}, X_{2}, X_{3}$, and $X_{4}$. Bacterial group $X_{1}$ uses oxygen under aerobic conditions and nitrate under anaerobic conditions as electron acceptor. Under anaerobic conditions bacterial groups $X_{2}, X_{3}$, and $X_{4}$ use $\mathrm{MnO}_{2}, \mathrm{Fe}(\mathrm{OH})_{3}$, and sulfate as an electron acceptor, respectively.

The one-dimensional advection dispersion differential equation with various reaction terms is solved numerically using the method of characteristics. The reaction part represented by (5) and (6) is calculated by the concentration difference obtained at the previous time step.

The model of solute transport with biological processes is highly complex, as it involves a large number of parameters. To determine the parameters values, sensitivity analysis is 
TABLE 2: Sequence of reduction reaction.

\begin{tabular}{ll}
\hline Bacterial groups & Reaction \\
\hline Aerobic respiration $\left(X_{1}\right)$ & $\mathrm{CH}_{2} \mathrm{O}+\mathrm{O}_{2} \rightarrow \mathrm{CO}_{2}+\mathrm{H}_{2} \mathrm{O}$ \\
Denitrification $\left(X_{1}\right)$ & $\mathrm{CH}_{2} \mathrm{O}+4 / 5 \mathrm{NO}_{3}{ }^{-}+4 / 5 \mathrm{H}^{+} \rightarrow \mathrm{CO}_{2}+2 / 5 \mathrm{~N}_{2}+7 / 5 \mathrm{H}_{2} \mathrm{O}$ \\
Manganese dioxide-reduction $\left(X_{2}\right)$ & $\mathrm{CH}_{2} \mathrm{O}+2 \mathrm{MnO}_{2} \rightarrow 2 \mathrm{Mn}^{2+}+3 \mathrm{H}_{2} \mathrm{O}+\mathrm{CO}_{2}$ \\
Iron hydroxide-reduction $\left(X_{3}\right)$ & $\mathrm{CH}_{2} \mathrm{O}+4 \mathrm{Fe}(\mathrm{OH})_{3}+8 \mathrm{H}^{+} \rightarrow 4 \mathrm{Fe}^{2+}+11 \mathrm{H}_{2} \mathrm{O}+\mathrm{CO}_{2}$ \\
Sulfate $\left(\mathrm{SO}_{4}{ }^{2-}\right)$-reduction $\left(X_{4}\right)$ & $\mathrm{CH}_{2} \mathrm{O}+1 / 2 \mathrm{SO}_{4}{ }^{2-}+1 / 2 \mathrm{H}^{+} \rightarrow \mathrm{CO}_{2}+1 / 2 \mathrm{HS}^{-}+\mathrm{H}_{2} \mathrm{O}$ \\
\hline
\end{tabular}

TABLE 3: Discretization, hydraulic parameters, and exchange coefficients.

\begin{tabular}{lccc}
\hline Parameter & Units & Soil & Soil sawdust \\
\hline$L$ (column length) & $\mathrm{cm}$ & 30 & 30 \\
$d$ (column diameter) & $\mathrm{cm}$ & 10 & 10 \\
$\Delta x$ & $\mathrm{~cm}$ & 0.5 & 0.5 \\
$\Delta t$ & $\mathrm{sec}$ & 30 & 30 \\
$u$ & $\mathrm{~cm} / \mathrm{sec}$ & $1.2 \times 10^{-4}$ & $1.4 \times 10^{-4}$ \\
$\alpha_{L}$ & $\mathrm{~cm}$ & 0.01 & 0.01 \\
$D_{M}$ & $\mathrm{~cm}^{2} / \mathrm{sec}$ & $1.0 \times 10^{-3}$ & $1.0 \times 10^{-3}$ \\
$\theta_{w}$ & - & 0.3 & 0.45 \\
$\theta_{\text {bio }}$ & - & 0.02 & 0.02 \\
$\theta_{\text {mat }}$ & - & 0.68 & 0.53 \\
$\alpha^{\prime}$ & $/$ day & 10 & 10 \\
$\beta^{\prime}$ & $/$ day & 0.005 & 0.005 \\
$\gamma^{\prime}$ & $/$ day & 0.00005 & 0.00005 \\
$n$ & - & 0.3 & 0.45 \\
$a$ & mm & 0.01 & 0.01 \\
$R$ (organic carbon ratio) & - & 0.4 & 0.4 \\
\hline
\end{tabular}

needed. The sensitivity analysis adopted in this application is the adjustment of parameters by increasing and decreasing their base values by one order of magnitude.

The discretization condition, hydraulic parameters, and exchange coefficients are presented in Table 3 . The discretization is chosen such as it meets the numerical stability criteria (Courant number $=u^{\prime} \times \Delta t / \Delta x \leq 1$, grid number $=\Delta x / \alpha_{L} \leq$ 2).

The bacterial growth in the model is assumed to follow the Monod-type kinetics [9]. The maximum growth rate, yield coefficient, inhibition constant and decay rate of all bacterial groups are presented in Table 4 . The decay rate is set to $15 \%$ of the maximum growth rate. The yield coefficients of the different bacterial groups were chosen according to the energy gain of the mediated redox reaction [3]. Therefore, the yield coefficient is highest for the aerobic bacteria and lower for the anaerobic bacteria.

3.3. Results and Discussion. Applicability of the developed model was checked by comparing the simulated results with the experimental data. The model simulated the two columns using the different values of parameter listed in Tables 3 and 4. The simulated concentrations of the electron acceptors such as oxygen, nitrate, manganese, iron, and sulfate, while the electron donor such as organic carbon agree well with

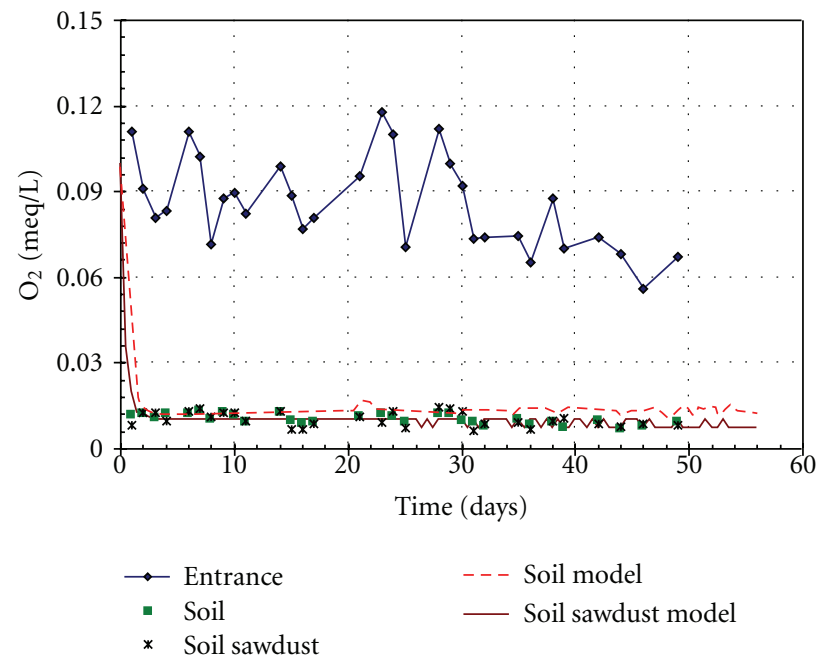

Figure 2: Measured and simulated $\mathrm{O}_{2}$ concentrations for two columns.

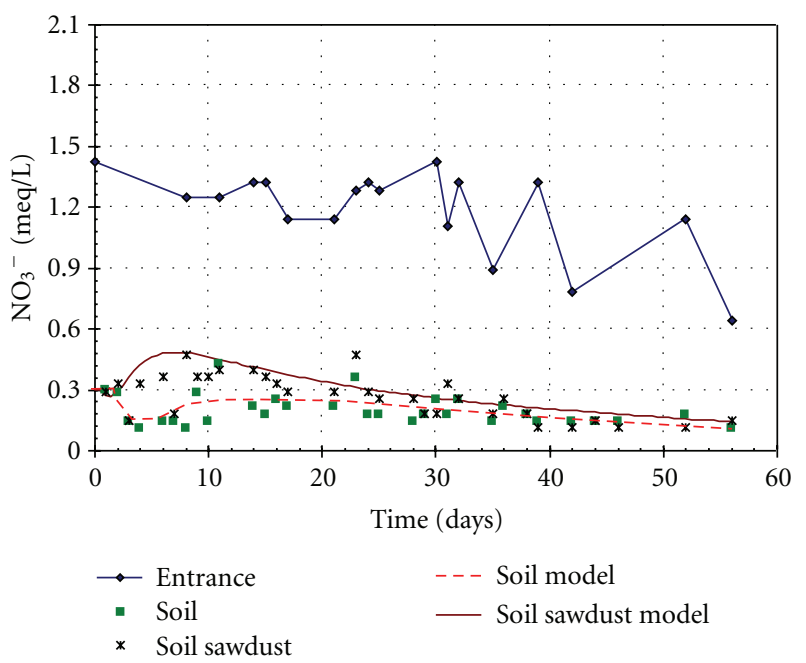

Figure 3: Measured and simulated $\mathrm{NO}_{3}{ }^{-}$concentrations for two columns.

the measured concentrations at the depth of $30 \mathrm{~cm}$ as shown in Figures 2 to 7.

The experimental results show that the column packed with soil alone having the low permeability $(1.45 \times$ $10^{-3} \mathrm{~cm} / \mathrm{sec}$ ) yielded reduction in electron acceptors, while the column packed with a mixture of $50 \%$ soil and $50 \%$ sawdust of relatively higher permeability $\left(7.39 \times 10^{-2} \mathrm{~cm} / \mathrm{sec}\right)$ 
TABLE 4: Biogeochemical parameters used for the two-dimensional redox model.

\begin{tabular}{|c|c|c|}
\hline Parameter & & Value \\
\hline \multirow{2}{*}{ Dispersivity } & $\alpha_{L}$ & $0.36 \mathrm{~cm}$ \\
\hline & $\alpha_{T}$ & $0.036 \mathrm{~cm}$ \\
\hline \multirow{2}{*}{ Half-saturation constant } & $K_{\mathrm{CH} 2 \mathrm{O}}$ & $0.10 \mathrm{mmol} / \mathrm{L}$ \\
\hline & $\begin{array}{l}K_{\mathrm{O}_{2}}, K_{\mathrm{NO}_{3}}, K_{\mathrm{MnO}_{2}}, K_{\mathrm{Fe}(\mathrm{OH})_{3}} \\
K_{\mathrm{SO}_{4}}\end{array}$ & $1.0 \times 10^{-3} \mathrm{mmol} / \mathrm{L}$ \\
\hline \multirow{3}{*}{ Aerobic bacteria $X_{1}$} & Yield coefficient $Y_{\mathrm{O}_{2}}$ & $\begin{array}{l}0.10 \mathrm{~mol} \text { cell-C/mol } \\
\text { OC }\end{array}$ \\
\hline & Max. growth $\nu_{\max }$ & $5.0 /$ day \\
\hline & Decay rate $v_{X_{1} \text { dec }}$ & $0.15 /$ day \\
\hline \multirow{3}{*}{ Denitrification bacteria $X_{1}$} & Yield coefficient $Y_{\mathrm{NO}_{3}}$ & $\begin{array}{l}0.05 \mathrm{~mol} \mathrm{cell}-\mathrm{C} / \mathrm{mo} \\
\text { OC }\end{array}$ \\
\hline & Max. growth $\nu_{\max }$ & $1.1 /$ day \\
\hline & Decay rate $\nu_{X_{1} \text { dec }}$ & $0.15 /$ day \\
\hline \multirow{3}{*}{ Mn(II)-reduction bacteria $X_{2}$} & Yield coefficient $Y_{\mathrm{MnO}_{2}}$ & $\begin{array}{l}0.04 \mathrm{~mol} \mathrm{cell-}-\mathrm{C} / \mathrm{mo} \\
\text { OC }\end{array}$ \\
\hline & Max. growth $\nu_{\max }$ & $0.75 /$ day \\
\hline & Decay rate $v_{X_{2} \text { dec }}$ & $0.15 /$ day \\
\hline \multirow{3}{*}{$\mathrm{Fe}(\mathrm{III})$-reduction bacteria $X_{3}$} & Yield coefficient $Y_{\mathrm{Fe}(\mathrm{OH})_{3}}$ & $\begin{array}{l}0.03 \mathrm{~mol} \text { cell- } \mathrm{C} / \mathrm{mo} \\
\text { OC }\end{array}$ \\
\hline & Max. growth $\nu_{\max }$ & $0.44 /$ day \\
\hline & Decay rate $v_{X_{3} \mathrm{dec}}$ & $0.15 /$ day \\
\hline \multirow{3}{*}{$\mathrm{SO}_{4}{ }^{2-}$ reduction bacteria $X_{4}$} & Yield coefficient $Y_{\mathrm{SO}_{4}{ }^{2-}}$ & $\begin{array}{l}0.02 \mathrm{~mol} \text { cell- } \mathrm{C} / \mathrm{mo} \\
\text { OC }\end{array}$ \\
\hline & Max. growth $\nu_{\max }$ & $0.24 /$ day \\
\hline & Decay rate $\nu_{X_{4} \mathrm{dec}}$ & $0.15 /$ day \\
\hline Inhibition coefficient for $\mathrm{Mn}^{2+}$ and $\mathrm{Fe}^{2+}$ & $\mathrm{IC}_{1}$ & $0.2 \mathrm{mmol} / \mathrm{L}$ \\
\hline Inhibition coefficient for $\mathrm{SO}_{4}{ }^{2-}$ & $\mathrm{IC}_{2}$ & $0.1 \mathrm{mmol} / \mathrm{L}$ \\
\hline Switching function & {$\left[\mathrm{O}_{2}\right]_{\text {thres }}$} & \\
\hline Threshold concentration of oxygen & & $0.015 \mathrm{mmol} / \mathrm{L}$ \\
\hline Slope of the switch function & $f_{\mathrm{sl}}$ & 40.0 \\
\hline
\end{tabular}

showed higher reduction in electron acceptors. The effect of sawdust is more visible in the enhancement of bacterial groups $X_{3}$ and $X_{4}$, which reduced the $\mathrm{Fe}(\mathrm{OH})_{3}$ and sulfate concentration.

Figure 2 shows the oxygen concentration as a function of time. The observed and simulated values show that oxygen was decreased very rapidly, which is due to the early start of aerobic and denitrifying bacteria group $X_{1}$ to consume oxygen as electron acceptor and organic carbon as electron donor. The rapid approach of steady state of oxygen concentration was reasonably reproduced with the model. The important parameter affecting the oxygen and nitrate concentration was the maximum growth rate of aerobic and denitrifying bacteria.

The nitrate concentration as a function of time is shown in Figure 3. The reduction of nitrate ion with time was simulated using the present model. The numerical solution shows comparable trend with the experiments. It may be apparent that the group of aerobic and denitrifying bacteria $X_{1}$ in the model starts to oxides the organic carbon with nitrate as an electron acceptor when oxygen concentration becomes limited. Switching between aerobic and anaerobic metabolism of bacteria $X_{1}$ was considered to take place at the oxygen threshold concentration at $0.015 \mathrm{mmol} / \mathrm{L}$. The observed and simulated data depict that the nitrate concentration from the soil-sawdust column is little higher than that of soil column, especially during the first twenty days and then after that no significant deference is seen between the two columns. The higher nitrate concentration from the soil-sawdust column would be resulted by high ammonium release from sawdust. Besides, higher water flow rate in the soil-sawdust column may be related, as Guerra et al. [12] demonstrated that the increases in flow velocity rate decreases the detention time necessary for denitrification.

Figure 4 shows manganese concentration as a function of time. The oxidation of organic carbon with $\mathrm{MnO}_{2}$ as electron acceptor is catalyzed by anaerobic bacteria $X_{2}$ in the model. As a result, $\mathrm{Mn}^{2+}$ ion is released in mobile phase. The overall manganese reduction rate can be directly derived from the observed increase in dissolved $\mathrm{Mn}^{2+}$ if the cation exchange with other cations is negligible. The exchange coefficient $\gamma^{\prime}$ 


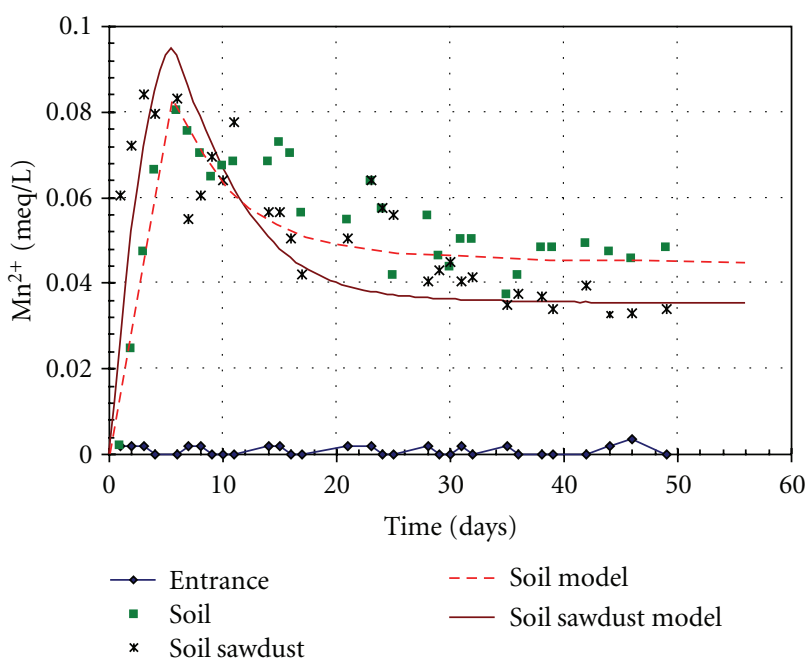

Figure 4: Measured and simulated $\mathrm{Mn}^{2+}$ concentrations for two columns.

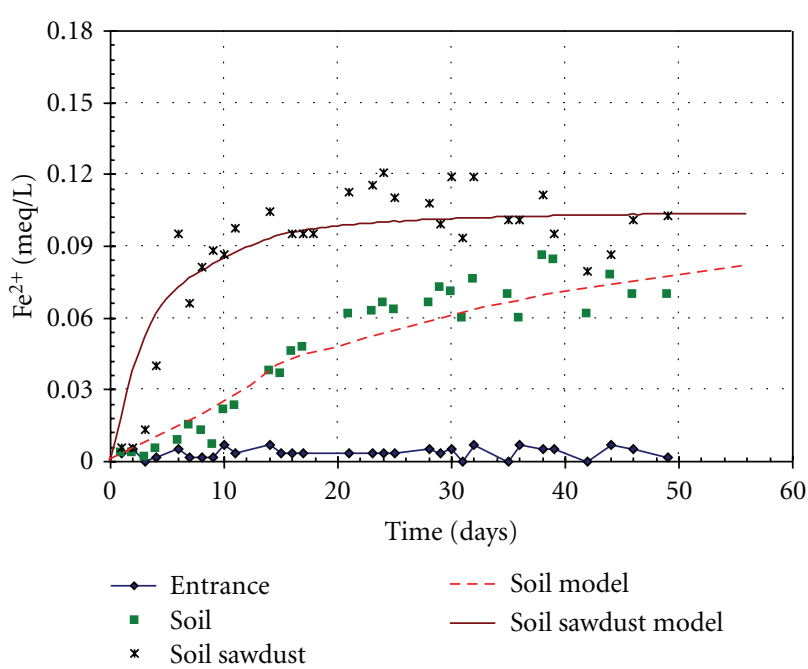

Figure 5: Measured and simulated $\mathrm{Fe}^{2+}$ concentrations for two columns.

in (7) for the matrix phase into biophase is found to be very small $(0.00005 /$ day $)$, indicating that manganese reduction is limited by the availability of $\mathrm{MnO}_{2}$. The observed and simulated data show that the $\mathrm{Mn}^{2+}$ concentration of soilsawdust column is a little higher than that of soil column during the first ten days then the $\mathrm{Mn}^{2+}$ concentration of soilsawdust column becomes lower than that of soil column, which is probably due to the faster reduction by enhanced organic carbon in soil-sawdust column.

Figure 5 shows the iron concentration as a function of time. Under anaerobic conditions bacterial group $X_{3}$ oxides the organic carbon with matrix $\mathrm{Fe}(\mathrm{OH})_{3}$ as an electron acceptor. The bacteria group $X_{3}$ reduces $\mathrm{Fe}(\mathrm{OH})_{3}$ and subsequently $\mathrm{Fe}^{2+}$ is released. The most important model parameter was the exchange coefficient between matrix $\mathrm{Fe}(\mathrm{OH})_{3}$ and microbially available $\mathrm{Fe}(\mathrm{OH})_{3}$ in the biophase.

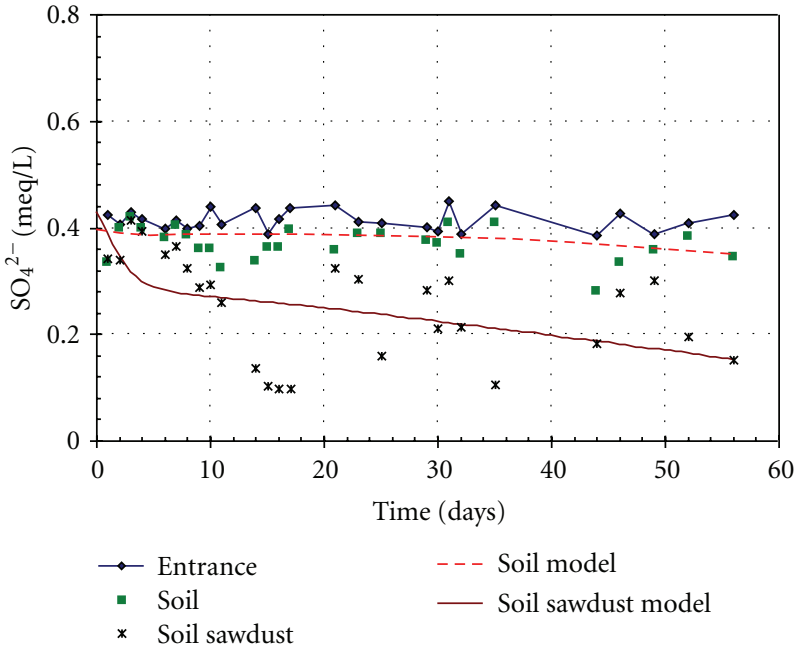

FIGURE 6: Measured and simulated $\mathrm{SO}_{4}{ }^{2-}$ concentrations for two columns.

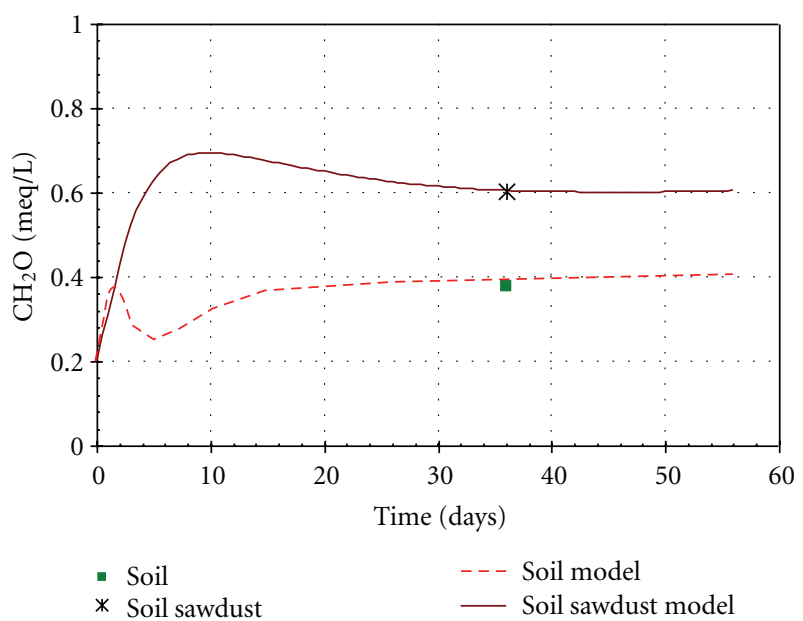

Figure 7: Measured and simulated $\mathrm{CH}_{2} \mathrm{O}$ concentrations for two columns.

The observed and simulated data show that the $\mathrm{Fe}^{2+}$ concentration of soil-sawdust column is higher than that of soil column, which is also probably the rapid reduction by enhanced organic carbon in soil-sawdust column compared with soil alone.

Figure 6 shows the experimental data and simulated sulfate concentration as a function of time.

The group of sulfate reducing bacteria $X_{4}$ in the model uses sulfate as an electron acceptor under anaerobic conditions. The observed and simulated results of sulfate concentration show a smaller decrease in the column packed with soil only, while significant decrease in sulfate concentration was observed in the column packed with soil sawdust. This may be attributed to the continuous supply of organic carbon from sawdust to the column. The temporal development of sulfate reduction in the columns is successfully reproduced with the model. The important model parameters were the exchange coefficient between mobile sulfate and microbially 


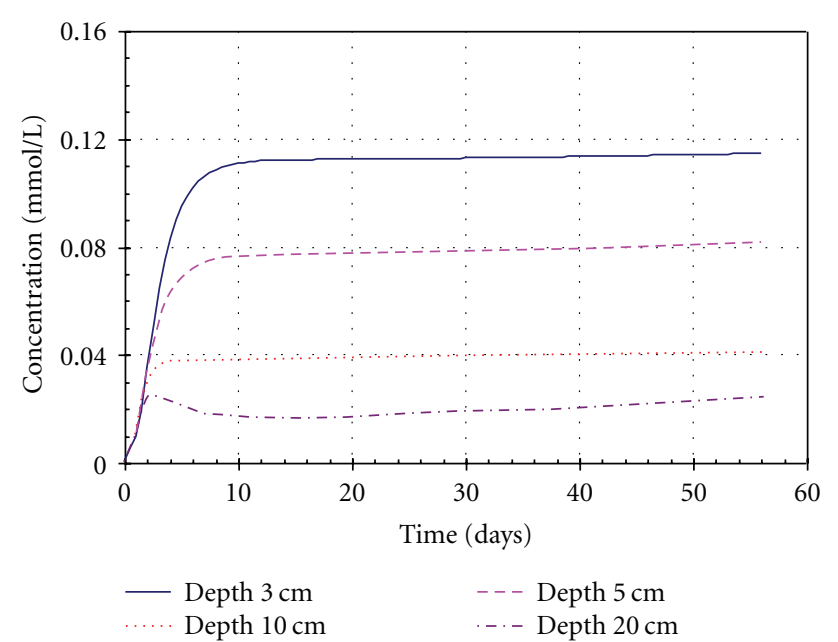

FIGURE 8: Simulation of bacterial growth versus time at different depths for the column packed with soil.

available sulfate in the biophase and the maximum growth rate of sulfate reducer bacteria.

Figure 7 shows the simulated organic carbon concentration as a function of time. The organic carbon concentrations for both soil column and soil-sawdust column were measured only once on 36th day of experiment. (Note that however, more frequent measurement of organic carbon concentration seemed necessary in the present experiment because significant changes in both columns took place.) The effect of soil-sawdust column on the carbon concentration increase shows approximately $50 \%$ as compared with the column packed with soil alone.

The simulated concentration is in good agreement with the measured values. The concentration of organic carbon of soil column increased in the first two days due to the little consumption by bacteria, after that the concentration of organic carbon decreased for next three days due to high growth of aerobic bacteria after that gradually approaches an equilibrium state. The model is able to calculate the relative contribution of the four bacterial groups to the total number of electrons transferred to organic carbon during the time of column experiment. The groups of aerobic and denitrifying bacteria $X_{1}$ contributed $68.5 \%$ of the transferred electrons. Anaerobic bacteria groups $X_{2}, X_{3}$, and $X_{4}$, which consume $\mathrm{MnO}_{2}, \mathrm{Fe}(\mathrm{OH})_{3}$, and sulfate as an electron acceptor, contribute $11 \%, 13.7 \%$, and $6.7 \%$ of the transferred electrons, respectively.

Figures 8 and 9 show the four bacterial growths with time at different depths for soil and soil-sawdust columns. Initially the bacteria tend to be acclimated to the new environmental conditions ( $\mathrm{pH}$, temperature, nutrients, etc.). Then, their population increase rapidly with time at an exponential growth in numbers, and the growth rate increases with time. After that with the exhaustion of nutrients and build-up of waste and secondary metabolic products, the growth rate has slowed down to the point where the growth rate equals the death.

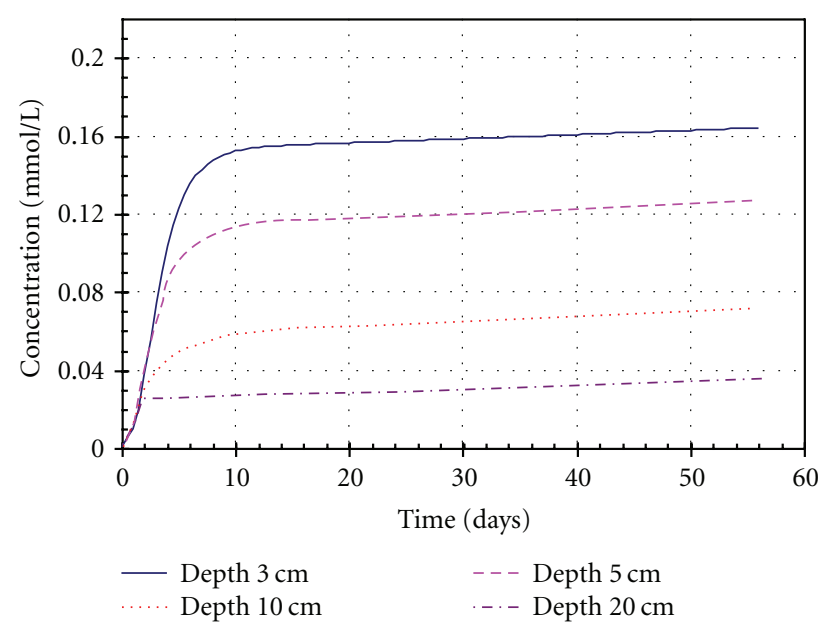

FIGURE 9: Simulation of bacterial growth versus time at different depth for the column packed with soil sawdust.

Figure 10 shows the distribution of the four bacterial groups along the column. The aerobic bacteria $X_{1}$ grow first. As long as the oxygen concentration exceeds $1.5 \times$ $10^{-2} \mathrm{mmol} / \mathrm{L}$, the metabolism of the anaerobic bacteria is inhibited. Afterwards the manganese reducers $X_{2}$ begin to grow, but their activity is limited by the higher availability of manganese. The iron reducers $X_{3}$ grow, and their activity increased by the high availability of iron. At the last half part of the column, the sulfate reducers bacteria group $X_{4}$ increases their activity, which is due to the limited concentration of oxygen and nitrate and high concentration of sulfate and available organic carbon as electron donor. The sulfate reducers bacteria group $X_{4}$ in the model begins to grow with high rate at depth $10 \mathrm{~cm}$, when most part of the column becomes anaerobic.

\section{Application to a Costal Aquifer}

Coastal groundwater biogeochemistry is becoming a popular topic among the groundwater researchers due to its vital role in the groundwater property change. Bacteria mediated reduction is one of the important processes which should be considered seriously in such kind of research activities. However, numerical approaches to simulate the distribution of reduced species in the coastal subsurface environment are not yet common in the field of hydrogeological modeling. In the present section a qualitative discussion is presented for a selected coastal aquifer. Geochemical properties of the groundwater in a coastal aquifer would change with the depth from aerobic state to anaerobic state. The bacteria mediated redox reactions are significant in the geochemical property changes of the subsurface water in a coastal aquifer. The availability of oxygen and other electron acceptors such as $\mathrm{NO}_{3}{ }^{-}, \mathrm{MnO}_{2}, \mathrm{Fe}(\mathrm{OH})_{3}$, and $\mathrm{SO}_{4}{ }^{2-}$ with the organic carbon as the electron donor encourage the different bacteria to activate and form reduced environments in the subsoil. The gradual decrease of oxygen with the depth allows bacteria to use other electron acceptors and form 


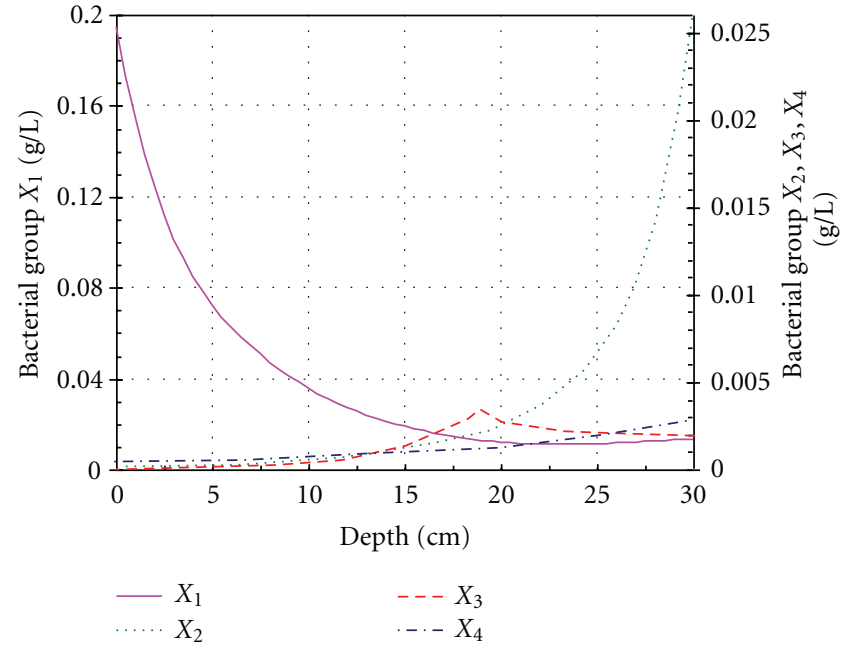

FIGURE 10: Simulated distribution of bacterial population along the soil column after 30 days.

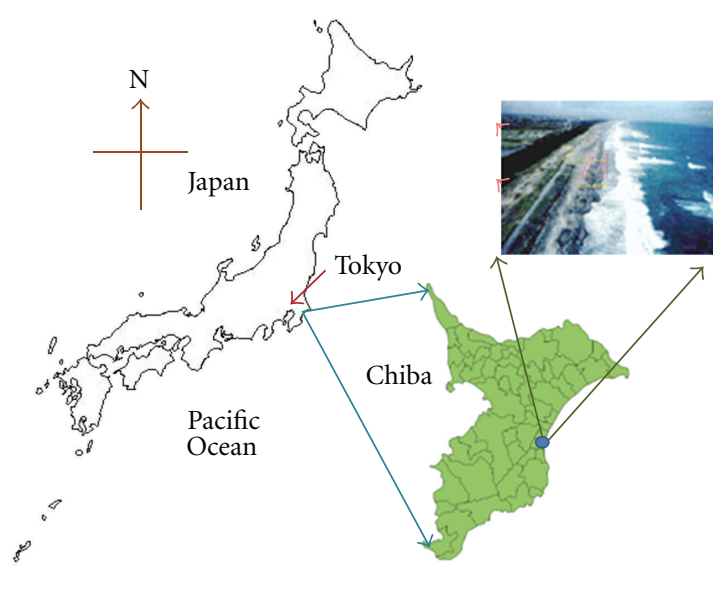

Figure 11: Location of the Kujyukurihama coast in Chiba prefecture, Japan.

$\mathrm{Mn}^{2+}-, \mathrm{Fe}^{2+}$ - and $\mathrm{HS}^{-}$-rich reduced environments. The salt water below the mixing zone is almost anaerobic in the coastal aquifer, and bacteria mediated reduction processes are dominant. Depending on the availability of organic carbon, a sequence of redox zones of increasing redox potential may develop at the down gradient of the aquifer; reduction zones of oxygen, $\mathrm{NO}_{3}{ }^{-}, \mathrm{MnO}_{2}, \mathrm{Fe}(\mathrm{OH})_{3}$, and $\mathrm{SO}_{4}{ }^{2-}$ can be developed if the organic carbon and corresponding electron acceptors are present in the aquifer under the bacterial mediation.

4.1. Site Description. Jinno et al. [13] researched on the geochemical properties of groundwater of the unconfined aquifer at Kujyukurihama coast in Chiba prefecture, Japan by analyzing the major ions (Figure 11). Salt water in the unconfined aquifer at Kujyukurihama coast has $-380 \mathrm{mV}$ oxidation-reduction potential at $8.0 \mathrm{~m}$ below the surface of the sand pit and the groundwater environment in the salt water region of the aquifer was considerably reduced.
TABLE 5: Measured chemical species at the site.

\begin{tabular}{|c|c|c|c|c|c|}
\hline Point & $\mathrm{A}$ & B & $\mathrm{C}$ & $\mathrm{D}$ & $\mathrm{E}$ \\
\hline $\mathrm{pH}$ & 7.2 & 8.2 & 6.9 & 7.6 & 7.9 \\
\hline $\mathrm{Na}^{+}(\mathrm{mg} / \mathrm{L})$ & 5900 & 4500 & 5500 & 120 & \\
\hline $\mathrm{K}^{+}(\mathrm{mg} / \mathrm{L})$ & 220 & 170 & 210 & 15 & \\
\hline $\mathrm{Ca}^{+}(\mathrm{mg} / \mathrm{L})$ & 120 & 190 & 210 & 15 & \\
\hline $\mathrm{Fe}^{+}(\mathrm{mg} / \mathrm{L})$ & 0.2 & $<0.1$ & $<0.1$ & $<0.1$ & \\
\hline $\mathrm{T}-\mathrm{Mn}^{+}(\mathrm{mg} / \mathrm{L})$ & 1 & 0.06 & 0.17 & 0.04 & \\
\hline $\mathrm{Cl}^{-}(\mathrm{mg} / \mathrm{L})$ & 9500 & 7300 & 9100 & 230 & \\
\hline $\mathrm{SO}_{4}{ }^{2-}(\mathrm{mg} / \mathrm{L})$ & 1200 & 1000 & 980 & 40 & \\
\hline $\mathrm{DO}(\mathrm{mg} / \mathrm{L})$ & (2.9) & $(4.1)$ & $<0.5$ & 3.5 & $<0.5$ \\
\hline DOC (mg/L) & 5 & 5 & 11 & $<1$ & \\
\hline TOC (mg/L) & 14 & 7 & 20 & 1 & \\
\hline ORP $(\mathrm{mV})$ & -99 & -66 & -380 & 78 & \\
\hline $\mathrm{S}^{2-}(\mathrm{mg} / \mathrm{L})$ & $<0.5$ & $<0.5$ & 11 & $<0.5$ & \\
\hline
\end{tabular}

The measurements conducted at different depths of this particular aquifer show high concentrations of reduced species in the anaerobic salt water region. As shown in Table 5, location $(\mathrm{C})$ shows high DOC concentration.

4.2. Model Setup. Firstly, a two-dimensional density dependent solute transport model is applied to obtain the steady state for the freshwater/salt water distribution and velocity distribution [6]. The groundwater properties in the subsurface of coastal aquifers are changed with depth according to the chloride concentration. In the shallow region, the water quality is close to the freshwater and in the deep region it is similar to the reduced salt water. However, the black coloured salt water with hydrogen sulphide odour is observed at the site when sand spit was excavated. This implies the precipitation of iron sulphide. Besides, precipitation of iron hydroxide can occur when the aerobic fresh water meets with the reduced salt water at the mixing zone. It is, therefore, necessary to include the following reactions with kinetic of precipitation rate:

Precipitation reaction for hydrogen sulphide:

$$
\mathrm{Fe}^{2+}+\mathrm{HS}^{-} \longrightarrow \mathrm{FeS}+\mathrm{H}^{+} .
$$

The corresponding precipitation reaction rate

$$
S_{\mathrm{FeS}}=K_{\mathrm{FeS}}\left[\mathrm{Fe}^{2+}\right]\left[\mathrm{HS}^{-}\right],
$$

where $S_{\mathrm{FeS}}$ is the rate of precipitation in $\mathrm{mol} / \mathrm{L} / \mathrm{sec} . K_{\mathrm{FeS}}$ is the reaction rate coefficient in $\mathrm{L} / \mathrm{mol} / \mathrm{sec}$. $\left[\mathrm{Fe}^{2+}\right]$ is the concentration of $\mathrm{Fe}^{2+}$ in $\mathrm{mol} / \mathrm{L}$. $\left[\mathrm{HS}^{-}\right]$is the $\mathrm{HS}^{-}$concentration in $\mathrm{mol} / \mathrm{L}$.

Precipitation reaction of iron hydroxide

$$
4 \mathrm{Fe}^{2+}+\mathrm{O}_{2}+8 \mathrm{OH}^{-}+2 \mathrm{H}_{2} \mathrm{O} \longrightarrow 4 \mathrm{Fe}(\mathrm{OH})_{3} .
$$

Equation (16) represents that $1 \mathrm{~mol} / \mathrm{L}$ of $\mathrm{Fe}^{2+}$ and $(1 / 4) \mathrm{mol} / \mathrm{L}$ of oxygen are consumed to precipitate $1 \mathrm{~mol} / \mathrm{L}$ of $\mathrm{Fe}(\mathrm{OH})_{3}$. 


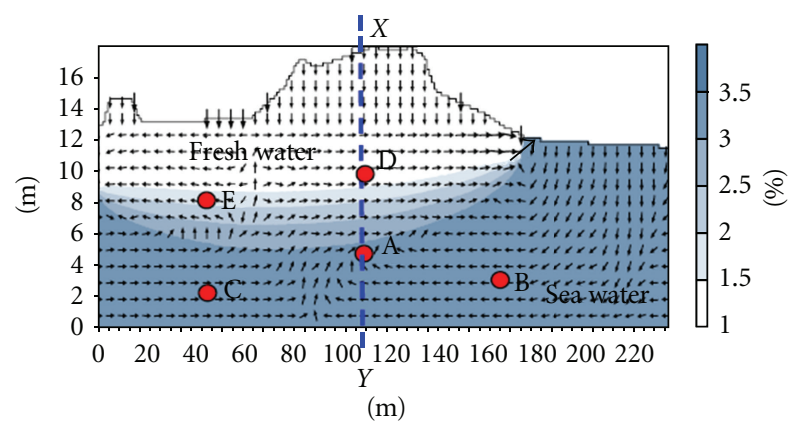

FIGURE 12: Steady state chloride distribution (\%) and velocity distribution for the two-dimensional density dependent solute transport model (selected cross-section of Kujyukurihama beach, Chiba, Japan). by [1]

The rate of the precipitation of $\mathrm{Fe}(\mathrm{OH})_{3}$ can be expressed

$$
S_{\mathrm{Fe}(\mathrm{OH})_{3}}=K_{\mathrm{Fe}(\mathrm{OH})_{3}}\left[\mathrm{Fe}^{2+}\right]\left[\mathrm{OH}^{-}\right]^{2} \mathrm{P}_{\mathrm{O}_{2}}
$$

where $S_{\mathrm{Fe}(\mathrm{OH})_{3}}$ is the rate of precipitation in mol/l/sec. $\mathrm{P}_{\mathrm{O}_{2}}$ is the oxygen partial pressure in atm.

Equations (15) and (17) are added to the right side of the $\mathrm{Fe}^{2+}$ transport equation (see (3)) as a sink term as

$$
\begin{aligned}
& \frac{\partial\left[\mathrm{Fe}^{2+}\right]}{\partial t}+u^{\prime} \frac{\partial\left(\left[\mathrm{Fe}^{2+}\right]\right)}{\partial x}+v^{\prime} \frac{\partial\left(\left[\mathrm{Fe}^{2+}\right]\right)}{\partial y} \\
& =\frac{1}{\theta_{w}} \frac{\partial}{\partial x}\left(\theta_{w} D_{x x} \frac{\partial\left[\mathrm{Fe}^{2+}\right]}{\partial x}+\theta_{w} D_{x y} \frac{\partial\left[\mathrm{Fe}^{2+}\right]}{\partial y}\right) \\
& \quad+\frac{1}{\theta_{w}} \frac{\partial}{\partial y}\left(\theta_{w} D_{y y} \frac{\partial\left[\mathrm{Fe}^{2+}\right]}{\partial y}+\theta_{w} D_{y x} \frac{\partial\left[\mathrm{Fe}^{2+}\right]}{\partial x}\right) \\
& +\sum_{j=1}^{2} S_{i, j}-S_{\mathrm{Fe}(\mathrm{OH})_{3}}-S_{\mathrm{FeS} .}
\end{aligned}
$$

Similar modifications of the corresponding mass balance equations for $\mathrm{HS}^{-}$and $\mathrm{O}_{2}$ in mobile phase, $\mathrm{Fe}(\mathrm{OH})_{3}$ and $\mathrm{FeS}$ in matrix phase are done depending on the stoichiometric coefficient in (14) and (16).

The initial distributions of the chemical species required for the two-dimensional redox model is assumed relative to the steady state chloride distribution which is obtained from the two-dimensional density dependent solute transport flow shown in Figure 12 [6]. The initial distribution of each chemical species accompanied with the steady state velocity distribution is input to the redox model in the simulation of bacteria mediated reduction.

4.3. Results and Discussion. In the selected aquifer, a layer of organic carbon has been found at the $12 \mathrm{~m}$ bottom. Therefore, in the numerical simulation, a $4 \mathrm{~m}$ thick organic carbon layer is assumed. This layer continuously supplies organic carbon for bacteria growth. In the numerical model, the matrix phase is considered as the organic carbon provider for the bacterial metabolism which takes place in the biophase. The precipitated $\mathrm{Fe}(\mathrm{OH})_{3}$ and $\mathrm{FeS}$ are assumed to deposit in the matrix phase. The behaviors of aerobic and anaerobic bacteria under assigned organic carbon distribution are simulated for ten years. The numerical results of bacterial growth show reduction of electron acceptors and consumption of organic carbon. Figure 13 shows the schematic diagram where the redox model is applied. The redox model parameters are listed in Table 6 . The precipitate rate coefficient for $\mathrm{Fe}(\mathrm{OH})_{3}$ or $\mathrm{FeS}$ is assigned by large number, because precipitation takes place quickly compared to reduction processes. Table 7 shows the assumed initial distribution of chemical species for redox model.

4.3.1. Aerobic Oxidation, Denitrification, and Growth of Bacteria $X_{1}$. Figure 14(a) shows the aerobic and denitrifying bacteria growth for ten years. Bacteria $X_{1}$ grow until 30 days and then the growth gradually decreases. After 2 years of calculation, the bacteria $X_{1}$ growth is not significant. According to Figure 14(a), however, bacteria $X_{1}$ growth is dominant in the freshwater region (Figure 12) and no or less growth can be seen in the anaerobic salt water region of the aquifer. The gradual decrease of $\mathrm{CH}_{2} \mathrm{O}$ in the aerobic freshwater region is the main reason for the decrease in bacteria $X_{1}$ growth after 30 days. Due to the consumption of $\mathrm{CH}_{2} \mathrm{O}$ in the freshwater region of biophase by bacteria $X_{1}, \mathrm{CH}_{2} \mathrm{O}$ in the freshwater region of the matrix phase decrease. This process is reasonably simulated as shown in Figure 15(a). The growth of bacteria $X_{1}$ in the freshwater region is controlled by the available $\mathrm{CH}_{2} \mathrm{O}$. As a result of continuous infiltration of rainwater with the assumed $8 \mathrm{mg} / \mathrm{L}$ of $\mathrm{O}_{2}$ concentration, there is enough $\mathrm{O}_{2}$ for bacteria $X_{1}$ growth. However, there is no $\mathrm{CH}_{2} \mathrm{O}$ supply for the freshwater region. Therefore, when the available $\mathrm{CH}_{2} \mathrm{O}$ is consumed, the growth of bacteria $X_{1}$ hinders. Moreover, in Figure 16(b), $\mathrm{NO}_{3}{ }^{-}$concentration decreases gradually due to the denitrifying process of bacteria $X_{1}$. Denitrification is rapid in the $\mathrm{O}_{2}$ low deeper area especially the elevation below $10.0 \mathrm{~m}$. The concentration variations of $\mathrm{O}_{2}$ and $\mathrm{NO}_{3}{ }^{-}$with the metabolism of bacteria $X_{1}$ imply that the redox model can simulate the growth of aerobic and denitrifying bacteria under the available $\mathrm{CH}_{2} \mathrm{O}$ appropriately. Figure 17 shows the spatial distribution of $\mathrm{O}_{2}$ after 10 years of simulation.

4.3.2. Reduction of $\mathrm{MnO}_{2}$ and Growth of Bacteria $X_{2}$. Bacteria $X_{2}$ reduce $\mathrm{MnO}_{2}$ to $\mathrm{Mn}^{2+}$ under anaerobic conditions. Figure 14(b) shows the growth of $\mathrm{MnO}_{2}$ reducing bacteria $X_{2}$. The decrease of $\mathrm{MnO}_{2}$ in the matrix phase (Figure 15(b)) corresponds well with the bacteria $X_{2}$ growth which is shown in Figure 14(b). Figure 16(d) shows the concentration of formed $\mathrm{Mn}^{2+}$ in mobile phase. Bacteria $X_{2}$ growth is significant in the anaerobic salt water region of the aquifer. Constant $\mathrm{CH}_{2} \mathrm{O}$ layer provides abundant electron donor environment which is favorable for bacterial growth. According to Figure 14(b), the bacteria $X_{2}$ growth increases up to 30 days. After that bacteria $X_{2}$ growth in the $\mathrm{CH}_{2} \mathrm{O}$ layer becomes lower. The reason for that is the availability of $\mathrm{MnO}_{2}$. Bacteria $\mathrm{X}_{2}$ use available $\mathrm{MnO}_{2}$ in the organic carbon region. Availability of $\mathrm{CH}_{2} \mathrm{O}$ and $\mathrm{MnO}_{2}$ under anaerobic condition is favorable for the growth of bacteria 


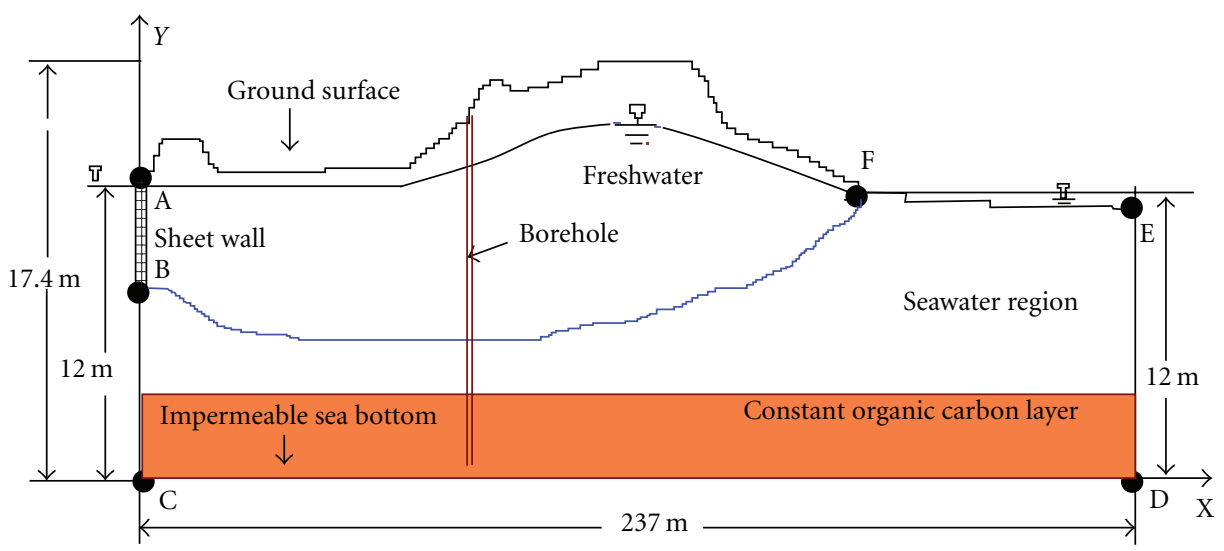

FIgURE 13: Schematic representation of the numerical model.

Concentration $(\mathrm{mg} / \mathrm{L})$

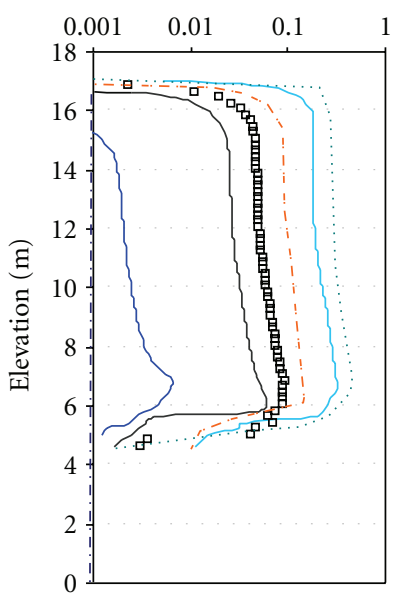

(a) Bacteria $X_{1}$

-. - Initial

-... 30 days

90 days
Concentration $(\mathrm{mg} / \mathrm{L})$

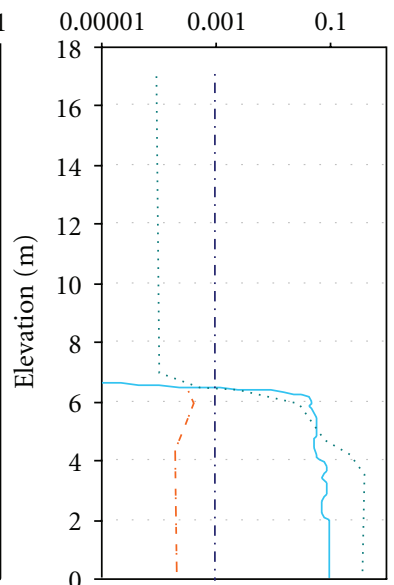

(b) Bacteria $X_{2}$
Concentration $(\mathrm{mg} / \mathrm{L})$

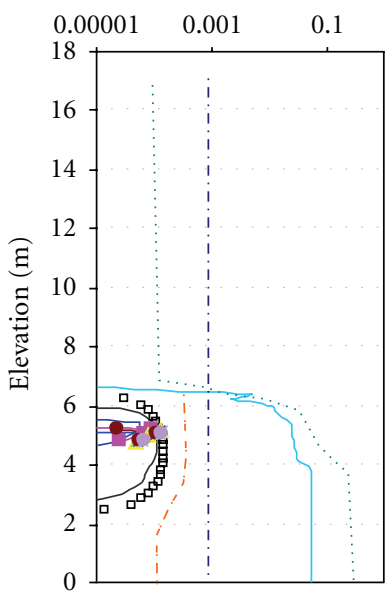

(c) Bacteria $X_{3}$
Concentration $(\mathrm{mg} / \mathrm{L})$

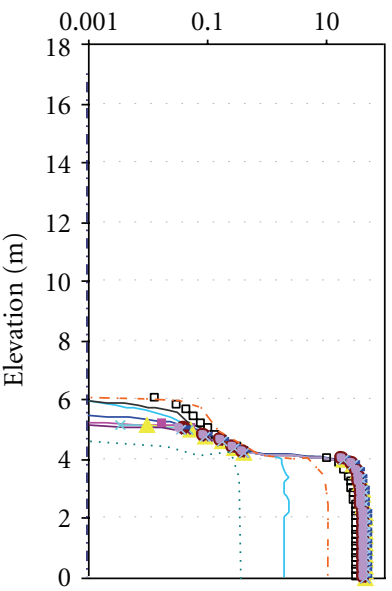

(d) Bacteria $X_{4}$

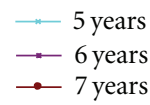

FIgURE 14: Numerical results for aerobic and anaerobic bacterial growth (along borehole no. 4).

$X_{2}$. However, gradual consumption of $\mathrm{MnO}_{2}$ in the $\mathrm{CH}_{2} \mathrm{O}$ layer forms a low $\mathrm{MnO}_{2}$ region, and then the bacteria $X_{2}$ growth in this area becomes low. After the consumption of all available $\mathrm{MnO}_{2}$, the growth of bacteria $X_{2}$ becomes zero. Availability of $\mathrm{CH}_{2} \mathrm{O}$ and $\mathrm{MnO}_{2}$ in the anaerobic region is the determining factors for bacteria $X_{2}$. Redox model is able to simulate the growth of bacteria $X_{2}$ appropriately under the assigned conditions. Figure 18 depicts the simulation results for the spatial distribution of formed $\mathrm{Mn}^{2+}$ after 10 years.

4.3.3. Reduction of $\mathrm{Fe}(\mathrm{OH})_{3}$, the Growth of Bacteria $\mathrm{X}_{3}$ and Reprecipitation of $\mathrm{Fe}(\mathrm{OH})_{3}$. The reduction of $\mathrm{Fe}(\mathrm{OH})_{3}$ occurs in the anaerobic region due to the metabolism of bacteria $X_{3}$ in the redox model. Figure 16(e) shows the formation of $\mathrm{Fe}^{2+}$ in the mobile phase due to the reduction of $\mathrm{Fe}(\mathrm{OH})_{3}$ in the biophase. Figure $14(\mathrm{c})$ shows the bacteria $X_{3}$ growth for ten years while in Figure 15(c) shows the concentration changes of $\mathrm{Fe}(\mathrm{OH})_{3}$ in the matrix phase. Up to 30 days, the growth of bacteria $X_{3}$ increases and after that it starts to decrease in the constant $\mathrm{CH}_{2} \mathrm{O}$ layer region. The decrease of the growth of bacteria $X_{3}$ in the constant $\mathrm{CH}_{2} \mathrm{O}$ layer is due to the consumption of $\mathrm{Fe}(\mathrm{OH})_{3}$ in the bottom of the aquifer. Even the $\mathrm{Fe}(\mathrm{OH})_{3}$ in the $\mathrm{CH}_{2} \mathrm{O}$ layer, becomes zero after 90 days, still there are some $\mathrm{Fe}(\mathrm{OH})_{3}$ above the $\mathrm{CH}_{2} \mathrm{O}$ layer. Therefore, bacteria $X_{3}$ grows in that region until all the $\mathrm{Fe}(\mathrm{OH})_{3}$ is reduced by bacteria $X_{3}$. In the region above constant $\mathrm{CH}_{2} \mathrm{O}$ layer, the determining factor is the availability of $\mathrm{CH}_{2} \mathrm{O}$ for bacteria $X_{3}$ growth while in the $\mathrm{CH}_{2} \mathrm{O}$ layer bacteria growth is determined by the availability of $\mathrm{Fe}(\mathrm{OH})_{3}$. The reprecipitation of formed $\mathrm{Fe}^{2+}$ takes place in the mixing zone, where $\mathrm{O}_{2}$ becomes available. The reduction of $\mathrm{Fe}(\mathrm{OH})_{3}$ takes place in the lower part of mixing zone and anaerobic salt water region of the aquifer at different rates according to the availability of $\mathrm{CH}_{2} \mathrm{O}$ and $\mathrm{Fe}(\mathrm{OH})_{3}$. The formed $\mathrm{Fe}^{2+}$ moves to the mixing zone with the advective flow and meets $\mathrm{O}_{2}$ and precipitates as $\mathrm{Fe}(\mathrm{OH})_{3}$. 


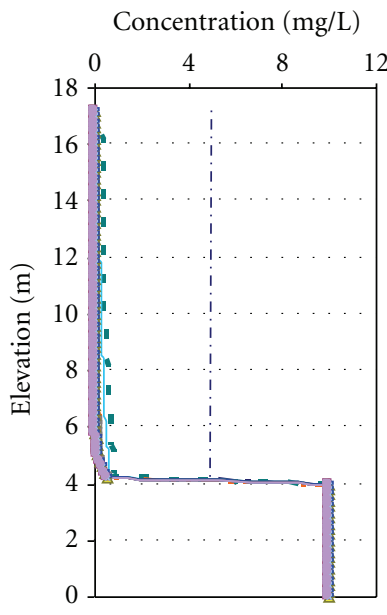

(a) Matrix $\mathrm{CH}_{2} \mathrm{O}$

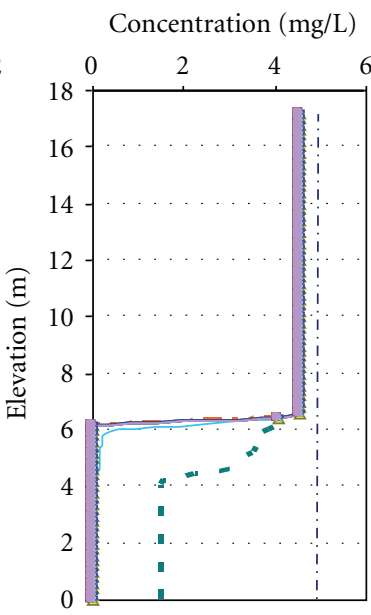

(b) Matrix $\mathrm{MnO}_{2}$

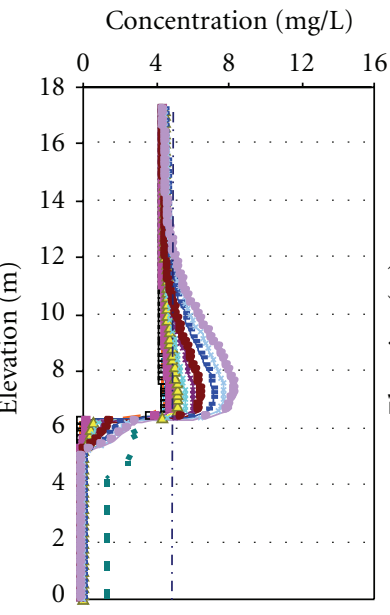

(c) Matrix $\mathrm{Fe}(\mathrm{OH})_{3}$

Concentration $(\mathrm{mg} / \mathrm{L})$

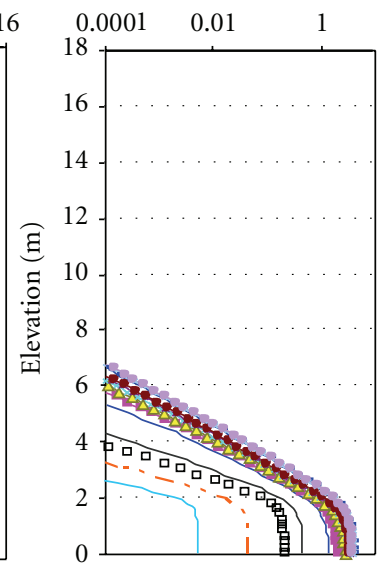

(d) Matrix FeS
-. - Initial
-.- 180 days
-2 years
$\longrightarrow 5$ years
- 3 years
$\rightarrow 6$ years
- 8 years
„ 9 years
— 90 days
- 1 year
$\triangle 4$ years
- 7 years
- 10 years

TABLE 6: Biogeochemical parameters used for the two-dimensional redox model.

\begin{tabular}{|c|c|c|}
\hline Parameter & & Value \\
\hline \multirow{2}{*}{ Dispersivity } & $\alpha_{L}$ & $0.36 \mathrm{~cm}$ \\
\hline & $\alpha_{T}$ & $0.036 \mathrm{~cm}$ \\
\hline \multirow{2}{*}{ Half-saturation constant } & $K_{\mathrm{CH}_{2} \mathrm{O}}$ & $0.10 \mathrm{mmol} / \mathrm{L}$ \\
\hline & $K_{\mathrm{O}_{2}}, K_{\mathrm{NO}_{3}}, K_{\mathrm{MnO}_{2}}, K_{\mathrm{Fe}(\mathrm{OH})_{3}}, K_{\mathrm{SO}_{4}}$ & $1.0 \times 10^{-3} \mathrm{mmol} / \mathrm{L}$ \\
\hline \multirow{3}{*}{ Aerobic bacteria $X_{1}$} & Yield coefficient $Y_{\mathrm{O}_{2}}$ & $0.10 \mathrm{~mol}$ cell-C/mol OC \\
\hline & Max. growth $v_{\max }$ & 3.0/day \\
\hline & Decay rate $v_{X_{1} \text { dec }}$ & $0.45 /$ day \\
\hline \multirow{3}{*}{ Denitrification bacteria $X_{1}$} & Yield coefficient $\mathrm{Y}_{\mathrm{NO}_{3}}$ & $0.08 \mathrm{~mol}$ cell-C/mol OC \\
\hline & Max. growth $v_{\max }$ & $2.25 /$ day \\
\hline & Decay rate $v_{X_{1} \mathrm{dec}}$ & $0.34 /$ day \\
\hline \multirow{3}{*}{$\operatorname{Mn}(\mathrm{II})$-reduction bacteria $X_{2}$} & Yield coefficient $Y_{\mathrm{MnO}_{2}}$ & $0.015 \mathrm{~mol}$ cell-C/mol OC \\
\hline & Max. growth $v_{\max }$ & $0.5 /$ day \\
\hline & Decay rate $v_{X_{2} \mathrm{dec}}$ & $0.075 /$ day \\
\hline \multirow{3}{*}{ Fe(III)-reduction bacteria $X_{3}$} & Yield coefficient $Y_{\mathrm{Fe}(\mathrm{OH})_{3}}$ & $0.015 \mathrm{~mol}$ cell-C/mol OC \\
\hline & Max. growth $v_{\max }$ & $0.5 /$ day \\
\hline & Decay rate $v_{X_{3} \mathrm{dec}}$ & $0.075 /$ day \\
\hline \multirow{3}{*}{$\mathrm{SO}_{4}^{2-}$ reduction bacteria $X_{4}$} & Yield coefficient $\mathrm{Y}_{\mathrm{SO}_{4}{ }^{2-}}$ & $0.015 \mathrm{~mol}$ cell-C/mol OC \\
\hline & Max. growth $v_{\max }$ & $0.45 /$ day \\
\hline & Decay rate $\nu_{X_{4} \mathrm{dec}}$ & $0.068 /$ day \\
\hline Inhibition coefficient for $\mathrm{Mn}^{2+}$ and $\mathrm{Fe}^{2+}$ & $\mathrm{IC}_{1}$ & $0.2 \mathrm{mmol} / \mathrm{L}$ \\
\hline Inhibition coefficient for $\mathrm{SO}_{4}{ }^{2-}$ & $\mathrm{IC}_{2}$ & $0.1 \mathrm{mmol} / \mathrm{L}$ \\
\hline \multicolumn{3}{|l|}{ Switching function } \\
\hline Threshold concentration of oxygen & {$\left[\mathrm{O}_{2}\right]_{\text {thres }}$} & $0.015 \mathrm{mmol} / \mathrm{L}$ \\
\hline Slope of the switch function & $f_{\mathrm{sl}}$ & 40.0 \\
\hline
\end{tabular}




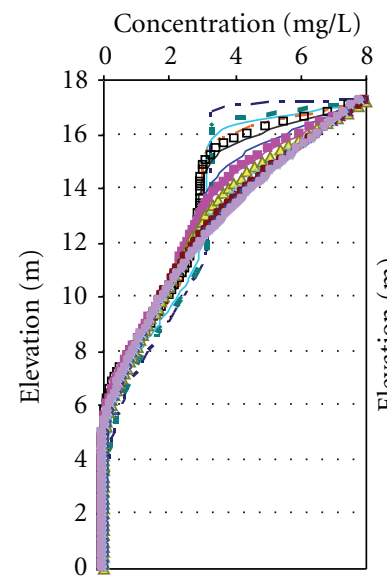

(a) Mobile $\mathrm{O}_{2}$

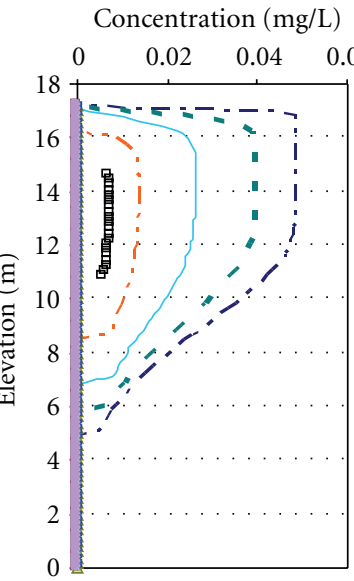

(b) Mobile $\mathrm{NO}_{3}^{-}$

Concentration $(\mathrm{mg} / \mathrm{L})$

Concentration $(\mathrm{mg} / \mathrm{L})$

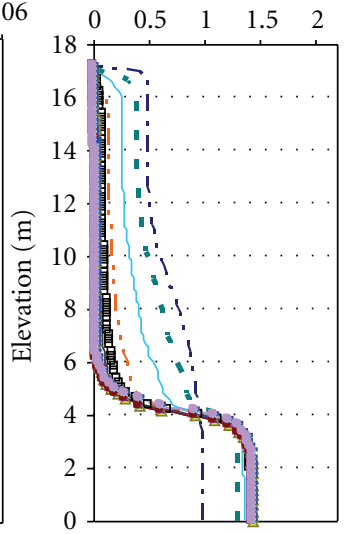

(c) Mobile $\mathrm{CH}_{2} \mathrm{O}$

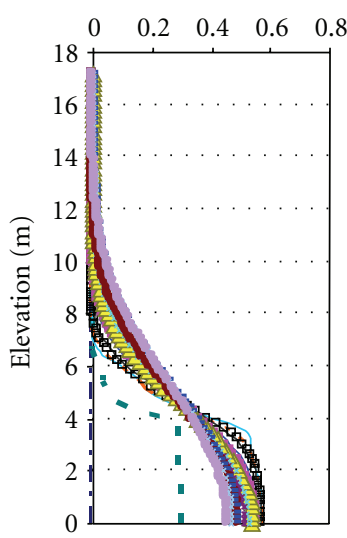

(d) Mobile $\mathrm{Mn}^{2+}$

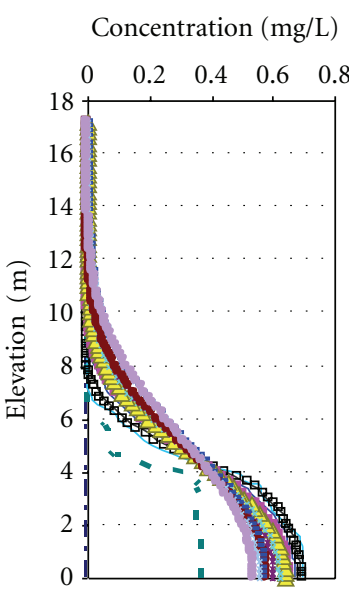

(e) Mobile Fe ${ }^{2+}$

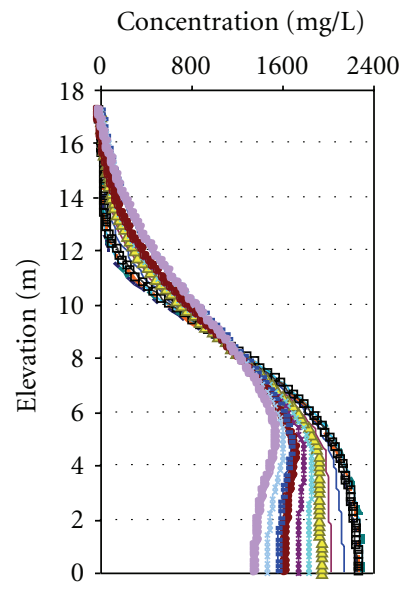

(f) Mobile $\mathrm{SO}_{4}{ }^{2-}$

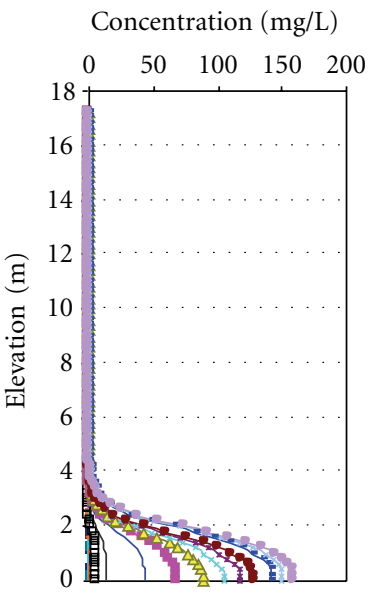

(g) Mobile $\mathrm{HS}^{-}$

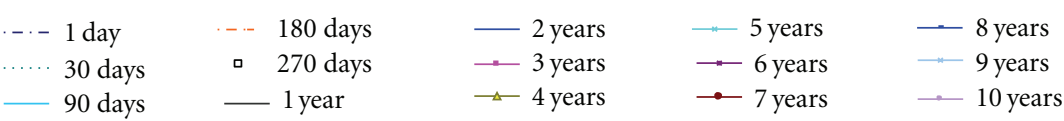

FIGURE 16: Numerical results for concentration variations of the mobile phase species (along borehole no. 4).

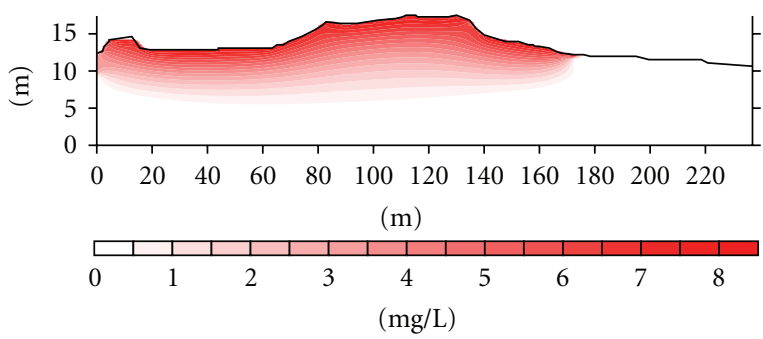

FIGURE 17: Simulation results for the spatial distribution of $\mathrm{O}_{2}$ after 10 years.

The reprecipitation of $\mathrm{Fe}(\mathrm{OH})_{3}$ is highlighted as the increase of $\mathrm{Fe}(\mathrm{OH})_{3}$ concentration in the matrix zone. In Figure $15(\mathrm{c})$, the gradual increase of $\mathrm{Fe}(\mathrm{OH})_{3}$ concentration in the mixing zone region (elevation between $6.0 \mathrm{~m}$ to $10.0 \mathrm{~m}$ ) depicts the precipitation of $\mathrm{Fe}(\mathrm{OH})_{3}$. The $\mathrm{Fe}^{2+}$ concentration

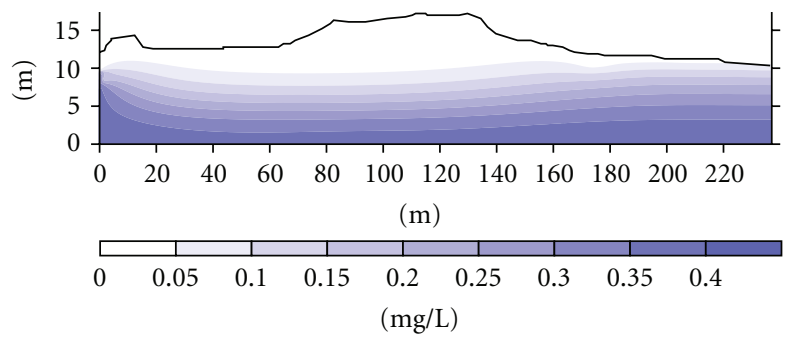

FIGURE 18: Simulation results for the spatial distribution of $\mathrm{Mn}^{2+}$ after 10 years.

increases around the $6.0 \mathrm{~m}$ elevation in the mobile phase (Figure 16(e)) is due the reduction of precipitated $\mathrm{Fe}(\mathrm{OH})_{3}$ in bottom edge of the mixing zone. However as a result of precipitation along the mixing zone, the concentration of $\mathrm{Fe}(\mathrm{OH})_{3}$ is increased. In the aerobic region, there is no 
TABLE 7: Initial chemical species distribution for redox model.

\begin{tabular}{|c|c|c|c|c|}
\hline \multirow[t]{2}{*}{ Chemical species } & \multicolumn{2}{|c|}{ Mobile phase (mg/L) } & \multirow[t]{2}{*}{ Biophase (mg/L) } & \multirow[t]{2}{*}{ Matrix phase $(\mathrm{mg} / \mathrm{L})$} \\
\hline & Fresh water & Salt water & & \\
\hline $\mathrm{O}_{2}$ & 0.34 & 0.0 & 0.0 & - \\
\hline $\mathrm{NO}_{3}{ }^{-}$ & 0.05 & 0.0 & - & - \\
\hline $\mathrm{MnO}_{2}$ & - & - & 0.05 & 5.0 \\
\hline $\mathrm{Fe}(\mathrm{OH})_{3}$ & - & - & 0.05 & 5.0 \\
\hline $\mathrm{Fe}^{2+}$ & - & - & - & - \\
\hline $\mathrm{Mn}^{2+}$ & - & - & - & - \\
\hline $\mathrm{CH}_{2} \mathrm{O}$ & 0.5 & 1.0 & 0.05 & 5.0 \\
\hline
\end{tabular}

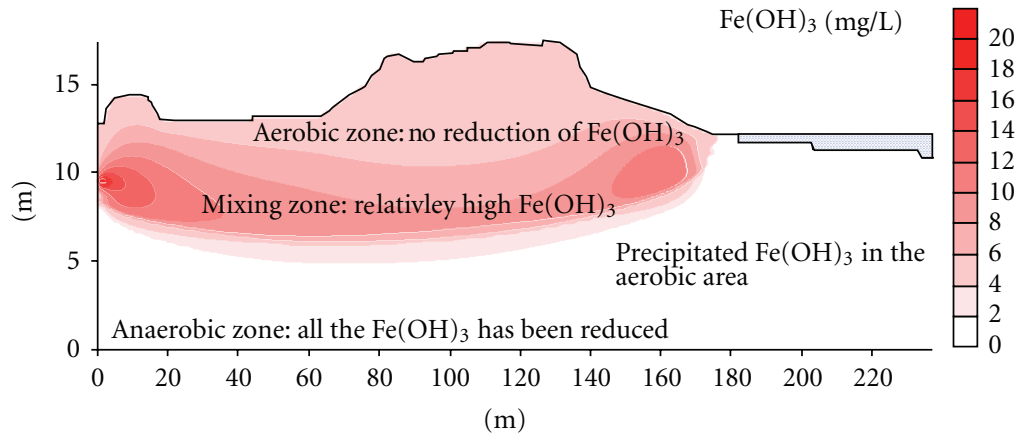

Figure 19: Simulation results for the spatial distribution of $\mathrm{Fe}(\mathrm{OH})_{3}$ after 10 years.

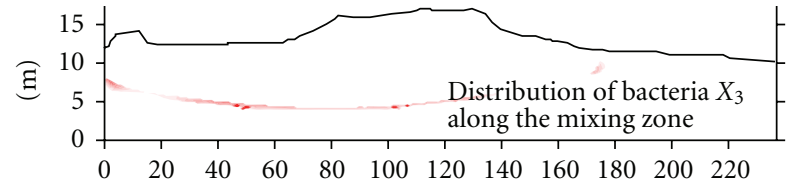

(m)

Figure 20: Simulation results for the spatial distribution of $X_{3}$ after 10 years.

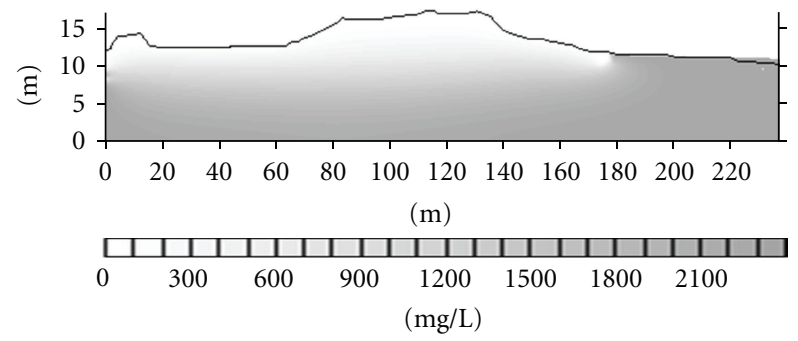

Figure 21: Spatial distribution of $\mathrm{SO}_{4}{ }^{2-}$ after 10 years of calculation.

growth of bacteria $X_{3}$ to reduce available $\mathrm{Fe}(\mathrm{OH})_{3}$. Therefore, $\mathrm{Fe}(\mathrm{OH})_{3}$ can be seen in the aerobic region of the simulation results. The numerical results for the bacteria $X_{3}$ and reduction/reprecipitation of $\mathrm{Fe}(\mathrm{OH})_{3}$ convince that the redox model simulates the bacteria $X_{3}$ growth and its related processes appropriately for available conditions. It is interesting to check the bacteria $X_{3}$ distribution in the crosssection, because $X_{3}$ is expected to reside along the mixing

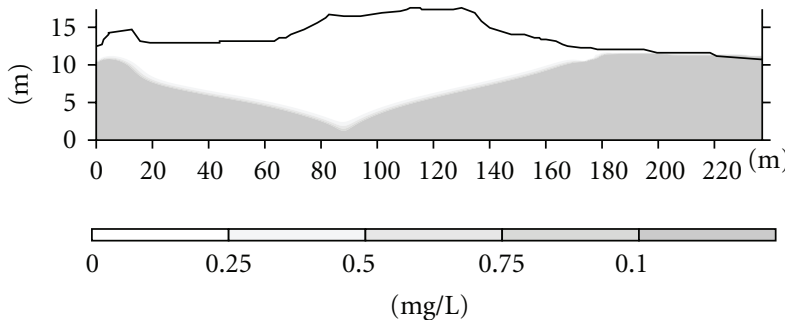

FIgURE 22: Spatial distribution of FeS after 10 years of calculation.

zone when reduction of $\mathrm{Fe}(\mathrm{OH})_{3}$ is almost completed and $\mathrm{Fe}^{2+}$ is then transported toward the mixing zone. Figures 19 and 20 depict the spatial distribution of $\mathrm{Fe}(\mathrm{OH})_{3}$ and $X_{3}$, respectively after ten years of simulation. As expected, $X_{3}$ resides below the high matrix zone of $\mathrm{Fe}(\mathrm{OH})_{3}$.

4.3.4. Reduction of $\mathrm{SO}_{4}{ }^{2-}$, Growth of Bacteria $\mathrm{X}_{4}$, and Precipitation of FeS. The growth of bacteria $X_{4}$ is determined by the availability $\mathrm{CH}_{2} \mathrm{O}$ and $\mathrm{SO}_{4}{ }^{2-}$. In the deeper part of the aquifer, especially in the organic carbon rich regions, there are abundant amount of $\mathrm{SO}_{4}{ }^{2-}$ and $\mathrm{CH}_{2} \mathrm{O}$ available to make a favorable condition for the growth of bacteria $X_{4}$. As a result of $\mathrm{SO}_{4}{ }^{2-}$ reduction $\mathrm{HS}^{-}$is formed. Figure $16(\mathrm{~g})$ shows the formation of $\mathrm{HS}^{-}$in the mobile phase. $\mathrm{HS}^{-}$in the mobile phase increases and consequently FeS starts to precipitate in the region, where $\mathrm{Fe}^{2+}$ and $\mathrm{HS}^{-}$are available. Figure 15(d) shows the precipitation of FeS in the matrix phase. FeS precipitation is significant at elevations below $6.0 \mathrm{~m}$. Mobile phase $\mathrm{SO}_{4}{ }^{2-}$ concentration profile is shown 
in Figure 16(f). The decrease of $\mathrm{SO}_{4}{ }^{2-}$ in the mobile phase and the increase of $\mathrm{HS}^{-}$emphasize the bacteria $X_{4}$ growth and reduction of $\mathrm{SO}_{4}{ }^{2-}$. Bacteria $X_{4}$ growth is shown in Figure 14(d). Bacteria $X_{4}$ growth increases up to 270 days and after that gradually it becomes to a stable with time in the $\mathrm{CH}_{2} \mathrm{O}$ layer region. The reduction of $\mathrm{SO}_{4}{ }^{2-}$ will continue due to the availability of $\mathrm{SO}_{4}{ }^{2-}$ and $\mathrm{CH}_{2} \mathrm{O}$ in the constant $\mathrm{CH}_{2} \mathrm{O}$ layer. In the Kujyukurihama beach, there is a low permeable alluvial deposit with organic carbon at the $12.0 \mathrm{~m}$ below the sea level. Table 5 shows high concentration of $\mathrm{S}^{2-}$ in the salt water region of the aquifer. These two observations provide a solid evidence for the reduction of $\mathrm{SO}_{4}{ }^{2-}$ in this particular aquifer under the anaerobic bacteria mediation. Figures 21 and 22 show the spatial distributions of $\mathrm{SO}_{4}{ }^{2-}$ and precipitated FeS for 10 years of simulation.

\section{Conclusion}

The results of the column experiment and the numerical solution demonstrate that the consumption of oxygen by bacteria $X_{1}$ took place within a few days and the subsequent reducing processes by bacteria $X_{2}, X_{3}$, and $X_{4}$ became active for approximately one week later. On the other hand, in the sand spit, the reducing processes under the assumed initial and boundary conditions seem to last several years. These differences arise from the different scale between the laboratory and field hydrogeological conditions. Besides, the parameters used in the reduction processes are not completely same as shown in Tables 4 and 6 for the onedimensional and in the two-dimensional simulations. However, two examples encourage the present modeling approach to be useful for groundwater management, specifically in the alluvial aquifer where groundwater quality is a crucial matter or enhancement of groundwater resources is planned. It can be also emphasized that the field sampling should be appropriately planned so that the modeling approach to be reliable for the practical application.

The results of the present numerical study also demonstrate that appropriate sampling frequency, locations, and chemical species could be determined in order to make efficient analyses of groundwater basins, where various management targets are planned.

\section{Acknowledgment}

The authors express the gratitude to Professor Tosao Hosokawa of Faculty of Engineering of Kyushu Sangyou University, Fukuoka, Japan, who provided his valuable experimental data.

\section{References}

[1] C. A. J. Appelo and D. Postma, Geochemistry, Groundwater and Pollution, Balkema Publishers, 2nd edition, 2006.

[2] W. Kinzelbach and W. Schäfer, "Modelling and design of in situ bioremediation measures," in Proceedings of the International Conference on Groundwater Quality Management (GQM '94), IAHS Publication no. 220, pp. 399-412, Tallinn, Estonia, September 1994.
[3] H. J. Lensing, M. Vogt, and B. Herrling, "Modeling of biologically mediated redox processes in the subsurface," Journal of Hydrology, vol. 159, no. 1-4, pp. 125-143, 1994.

[4] K. S. Hunter, Y. Wang, and P. Van Cappellen, "Kinetic modeling of microbially-driven redox chemistry of subsurface environments: coupling transport, microbial metabolism and geochemistry," Journal of Hydrology, vol. 209, no. 1-4, pp. 53$80,1998$.

[5] O. Eljamal, K. Jinno, and T. Hosokawa, "Modeling of solute transport with bioremediation processes using sawdust as a matrix," Water, Air, and Soil Pollution, vol. 195, no. 1-4, pp. 115-127, 2008.

[6] E. D. P. Perera, K. Jinno, and Y. Hiroshiro, "Bacteria-mediated reduction and precipitation of $\mathrm{Fe}(\mathrm{OH})_{3}$ and $\mathrm{FeS}$ in the subsurface of a coastal aquifer: a numerical investigation," Water Quality, Exposure and Health, vol. 2, no. 1, pp. 15-30, 2010.

[7] D. Schäfer, W. Schäfer, and W. Kinzelbach, "Simulation of reactive processes related to biodegradation in aquifers. 1. Structure of the three-dimensional reactive transport model," Journal of Contaminant Hydrology, vol. 31, no. 1-2, pp. 167186, 1998.

[8] L. A. Schipper, G. F. Barkle, and M. Vojvodic-Vukovic, "Maximum rates of nitrate removal in a denitrification wall," Journal of Environmental Quality, vol. 34, no. 4, pp. 1270-1276, 2005.

[9] B. E. Rittmann and P. L. McCarty, Environmental Biotechnology: Principles and Applications, McGraw-Hill, New York, NY, USA, 2001.

[10] D. Schäfer, W. Schäfer, and W. Kinzelbach, "Simulation of reactive processes related to biodegradation in aquifers. 2 . Model application to a column study on organic carbon degradation," Journal of Contaminant Hydrology, vol. 31, no. 1-2, pp. 187-209, 1998.

[11] T. H. Christensen, P. L. Bjerg, S. A. Banwart, R. Jakobsen, G. Heron, and H. J. Albrechtsen, "Characterization of redox conditions in groundwater contaminant plumes," Journal of Contaminant Hydrology, vol. 45, no. 3-4, pp. 165-241, 2000.

[12] G. Guerra, K. Jinno, Y. Hiroshiro, and K. Nakamura, "Multicomponent solute transport model with cation exchange under redox environment and its application for designing the slow infiltration setup," Memoirs of the Faculty of Engineering, Kyushu University, vol. 64, no. 1, pp. 78-100, 2004.

[13] K. Jinno, T. Hosokawa, Y. Hiroshiro, and M. Ohgushi, "Mixing of fresh and salt groundwater in a sandy beach using pipe draining to extend the unsaturated zone," in Proceedings of the 3rd International Conference on Future Groundwater Resources at Risk, pp. 641-648, Lisbon, Portugal, 2001. 

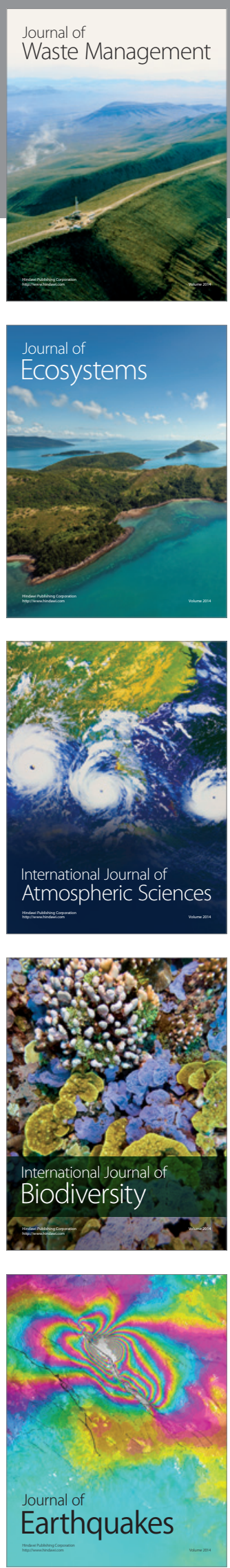
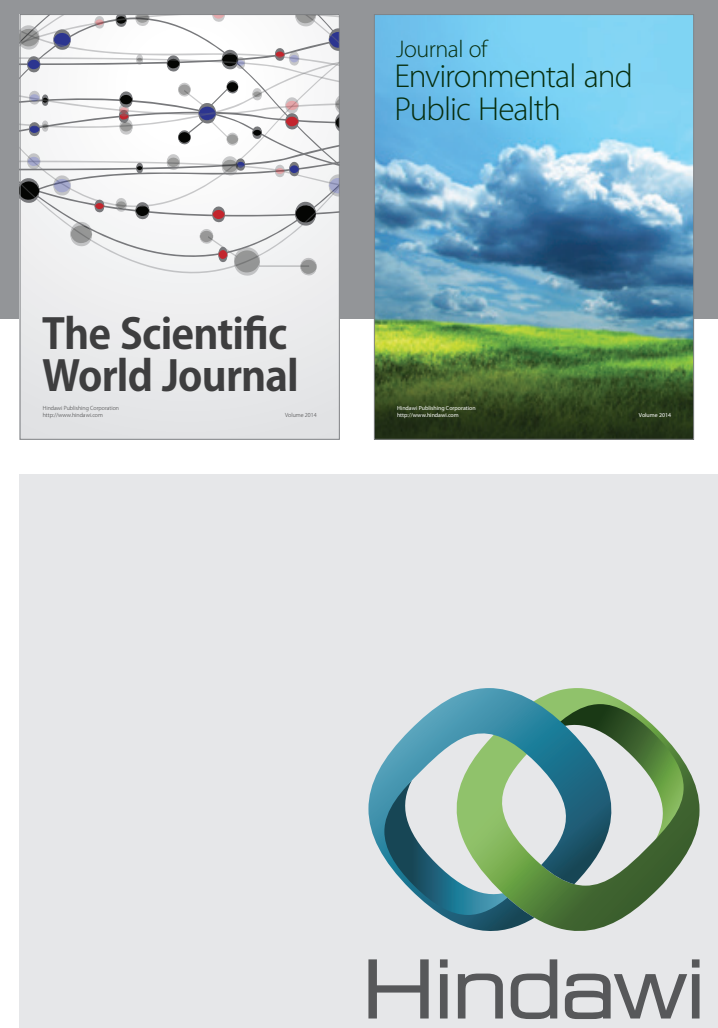

Submit your manuscripts at

http://www.hindawi.com
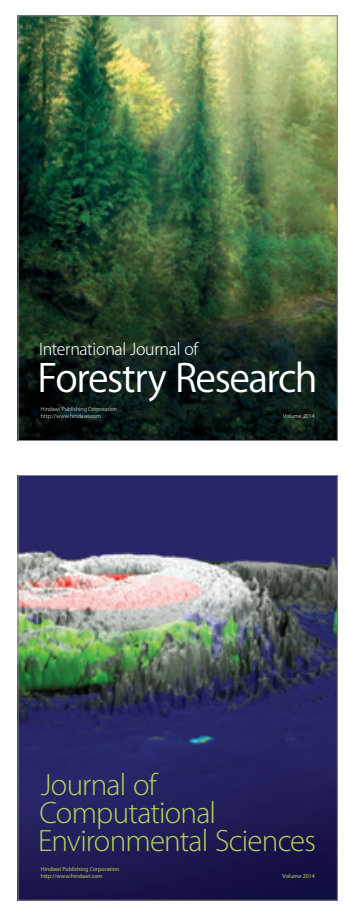
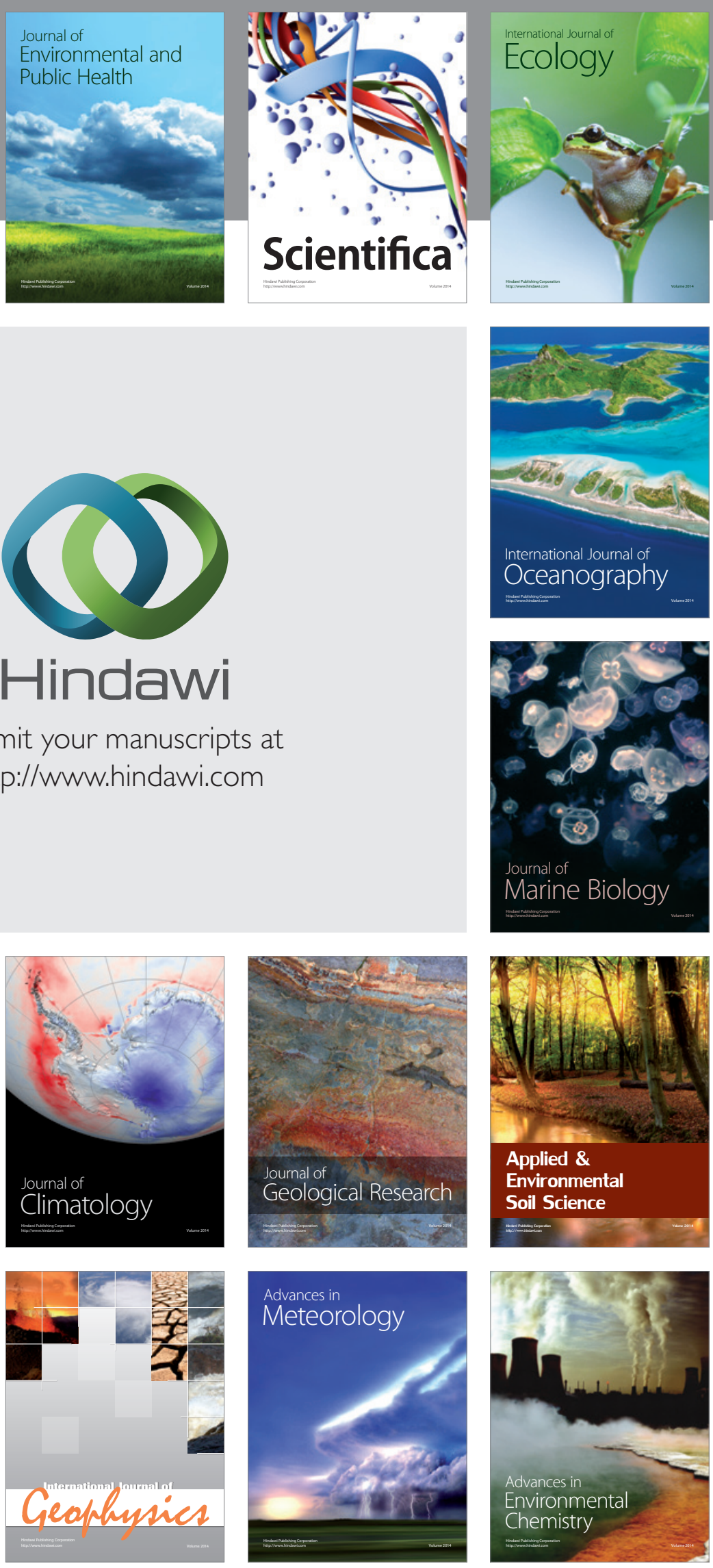